\title{
The Role of Ground Beetles (Coleoptera: Carabidae) in Weed Seed Consumption: A Review
}

\author{
Sharavari S. Kulkarni, Lloyd M. Dosdall, and Christian J. Willenborg*
}

\begin{abstract}
Weed management is a challenge in all agroecosystems. Given the negative consequences associated with herbicide-based weed management, it is important to consider integrated weed management options with emphasis on strategies such as biological control. Postdispersal weed seed predation by granivorous and omnivorous carabid beetles results in substantial natural suppression of weed populations. Although the role of ground beetles as "generalist predators" in various agroecosystems is known, their contribution to weed management is not well recognized. In this context, this review presents an account of carabids and their granivorous nature, the importance of a seed diet in the life histories of different carabid groups, factors affecting granivory, and their potential role in weed seed management. Below, we discuss the interrelationships among various factors influencing weed seed consumption by carabids, its consequences for weed management, and the need for future research. Key words: Biological control, carabids, integrated weed management, postdispersal seed consumption, weeds.
\end{abstract}

Among all agricultural practices, the management of weeds has historically been the most resourcedemanding practice performed by growers, requiring considerable time and monetary resources (Holm and Johnson 2009). For example, total weed control costs in the United States alone have been estimated to be approximately 27 billion USD $\mathrm{yr}^{-1}$ (Pimentel et al. 2005). In Canada and elsewhere, weed management creates challenges in various agroecosystems besides the costs incurred in weed management operations. For instance, a single species such as Canada thistle, Cirsium arvense (L.) Scop., can cause up to $60 \%$ yield reduction in canola (Brassica napus L. and Brassica rapa L.) (Canola Council of Canada 2014a). Similarly, the cost of controlling wild oat (Avena fatua L.) across the Prairie Provinces of Canada has been estimated at $\$ 500$ million annually (Leeson et al. 2005).

In North America, herbicide-based weed management has been the major strategy for weed control in agroecosystems (Ghersa et al. 2000). In fact, 20 to $30 \%$ of the cost of producing a crop can be attributed to herbicide application (Derksen et al. 2002). Excessive dependence on herbicides has resulted in problems such as selection for

\footnotetext{
DOI: 10.1614 /WS-D-14-00067.1

* First and second authors: Graduate student, Professor, Department of Agricultural, Food, and Nutritional Science, $410 \mathrm{Ag} /$ Forestry Building, University of Alberta, Edmonton, Alberta, Canada T6G 2P5; third author: Assistant Professor, Department of Plant Sciences, College of Agriculture and Bioresources, University of Saskatchewan, 51 Campus Drive, Saskatoon SK, Canada. Corresponding author's E-mail: sharavar@ualberta.ca
}

herbicide-resistant weeds (Holm and Johnson 2009), nontarget spray drift, persistent chemical residues, and environmental pollution (Boyetchko et al. 2009). Further, high application rates of herbicides and other agrochemicals for pest management negatively affect crop microhabitats, thereby influencing beneficial arthropod species and affecting biodiversity (Navntoft et al. 2006).

Hence, a weed management approach relying on the application of chemical herbicides alone has several negative consequences, and the integration of several small "hammers" of weed management in an integrated system can help to overcome such negative consequences (Liebman and Gallandt 1997; Swanton and Murphy 1996). Integrated weed management (IWM) has been defined as the "application of numerous alternative weed control measures, which may include cultural, genetic, mechanical, biological, and chemical means of weed control" (Swanton and Murphy 1996). Among these, biological control of weeds using arthropods provides a potential alternative to herbicide applications, and also serves as a sustainable option for long-term weed management (Boyetchko et al. 2009). Biological control can be combined harmoniously with other weed management practices. Some predispersal insect seed consumers have already been used for biological control of weeds (Julien 1992). Postdispersal seed consumption can cause direct death of weedy plants (Crawley 2000; Harper 1977), and serves as a critical factor determining the population dynamics of weeds in agroecosystems (Crawley 2000; Lundgren 2009). 
In agroecosystems, both vertebrates (e.g., rodents, birds), and invertebrates (mainly insects) contribute to the postdispersal consumption of weed seeds (Heggenstaller et al. 2006; Honek et al. 2009; Inouye 1980; Louda 1989; Menalled et al. 2007; Ward et al. 2011). Among vertebrates, rodents are an important group of seed feeders (Hulme 1998, 2002; Kollmann et al. 1998), and some studies suggest that rodents contribute to an equal or greater proportion of seed consumption than invertebrates (Brust and House 1988; Cardina et al. 1996; Harrison et al. 2003; Menalled et al. 2000b; Watson et al. 2003; Westerman et al. 2003a). However; rodents might not prefer disturbed habitats such as agricultural fields (Brust and House 1988; Hulme 1998; 2002; Kollmann et al. 1998). For example, Brust and House (1988) compared seed predation rates under zero tillage and conventional tillage conditions and found that rodents actually contributed significantly more weed seed removal in the zero-tilled (less disturbed) fields.

Among invertebrates, insects comprise an important group of seed feeders (Gallandt et al. 2005; Hulme 1998; Lundgren 2005; Mauchline et al. 2005; Menalled et al. 2000b; Nystrand and Granstrom 2000), and their role in weed seed consumption has gained attention in recent years due to their prominence in agroecosystems (Lundgren 2009). The granivorous taxa of the temperate region are dominated by crickets and carabid beetles (Honek et al. 2003; Lundgren et al. 2006; O'Rourke et al. 2006), and to a lesser degree include some caterpillars (Lepidoptera), weevils (Curculionidae), rove beetles (Staphylinidae) and isopods (Lundgren et al. 2013; Saska 2008a). In the tropics (Albert et al. 2005; Chauhan et al. 2010; Motzke et al. 2013), semiarid (Baraibar et al. 2009), and arid habitats (Hulme 1998), ants play an important role in seed feeding.

Among invertebrate seed consumers, carabid beetles are an important taxonomic group in temperate agroecosystems (Zhang et al. 1997), and are the focus of this review paper in view of their abundance and importance in Canadian agroecosystems. Their role as arthropod predators is well-known in various agroecosystems, and carabids are considered important biological control agents (Holland and Luff 2000; Kromp 1999; Marko and Kadar 2005). However, evidence from recent studies underlines their potential effectiveness as postdispersal seed feeders of many important agricultural weeds (Bohan et al. 2011; Honek et al.
2003; Jonason et al. 2013; Lundgren 2005; Lundgren et al. 2013; O'Rourke et al. 2006), capable of exerting significant constraints on weed population size. For example, seed consumption by carabids can help to reduce seed stock of a weed species in the range of 65 to $90 \%$ (Honek et al. 2005). Weed seed consumption rates of up to $74 \%$ have been documented for three weed species: field violet, Viola arvensis Murr.; chickweed, Stellaria media (L.) Vill., and shepherd's-purse, Capsella bursa-pastoris (L.) Medik., in agricultural habitats (Jonason et al. 2013). Estimates of seed consumption rates by carabid species differ among various agroecosystems, and depend on crop type, activitydensity, seasonality, presence of noncrop habitats, and extent of disturbance (Gaines and Gratton 2010). Reports indicate that rates of consumption also vary from moderate consumption rates of 200 seeds $\mathrm{m}^{-2}$ day $^{-1}$ (Gaines and Gratton 2010) up to 1,000 seeds $\mathrm{m}^{-2} \mathrm{day}^{-1}$ in some cases (Honek et al. 2003). More importantly, some carabid species are capable of removing weed seeds that are dispersed on the ground, as well as those that are buried in the soil as a result of agricultural operations (White et al. 2007). This provides an advantage to carabids over other seed consumers that lack the capacity to track buried seeds (Van der Wall 1998). Seed consumption by carabids at the soil surface intercepts the entry of seeds into the soil seed bank after seed rain (Bohan et al. 2011). Capacity to consume buried seeds can further reduce the net seed stock of the soil (Bohan et al. 2011). Such seed consumption thus influences soil seed banks, consequently influencing the community structure of weed populations (Bohan et al. 2011). An understanding of the factors that influence weed seed consumption by ground beetles is very important for facilitating natural suppression of weed populations.

To date, most studies on ground beetles have focused on their distribution (Holland et al. 1999; Honek and Jarosik 2000; Saska et al. 2008; Thiele 1977), various aspects of their life histories and ecology (Lövei and Sunderland 1996), species composition, and the effects of agricultural practices on their distribution (Booij and Noorlander 1992; Cárcamo et al. 1995; Dritschilo and Wanner 1980; Ellsbury et al. 1998; Kromp 1989; Lundgren et al. 2006). However, there is a growing interest in habits of primarily granivorous and omnivorous species, and recent studies have focused on weed seed consumption under field conditions (Gaines and Gratton 2010; Honek et al. 2003, 2005; 
Jonason et al. 2013; Lundgren et al. 2013; Menalled et al. 2007). Despite this, their potential as biological control agents of weeds, and their contribution to ecological services such as postdispersal weed seed consumption, remains to be fully understood. Understanding the role of carabids in weed management requires a thorough understanding of their bioecology, behavior, dietary preferences, and the factors influencing their activity. Knowledge of the interrelations among these factors can contribute to designing strategies that can augment carabid activity and enhance weed seed consumption. Biological control through augmentation of the activity of seed-feeding carabids as a weed management strategy can be integrated with other tactics of the integrated system. Implementing agricultural management practices that compliment carabid activity has implications for effective weed management while conserving agroecosystem biodiversity and sustainability.

Prior reviews on the role of granivory in biological control of weeds have focused mainly on the bioecology of granivorous taxa and their contributions to weed seed consumption (Lundgren 2009). Our review thus focuses mainly on granivory of Carabidae and expands on the aspects of carabid weed seed consumption presented in earlier works (Lundgren 2009), and provides an agroecosystems context to understand the role of granivory in weed management. In this review, we provide a detailed overview of the importance of carabids as seed consumers and the major groups of granivorous carabids, various aspects of their granivorous habit, and an account of the factors influencing granivory in major agroecosystems. We have presented here a detailed account of agronomic and crop management practices and their influences on the efficacy of weed seed-consuming carabid communities. We have further identified the knowledge gaps in understanding carabid seed-feeding ecology and discussed interrelations between factors influencing carabid activity and their implications for weed seed management.

\section{Carabid Beetles and Granivory}

Biology of Carabidae. Most carabids spend all of their life stages on or in the soil rhizosphere. Carabid eggs are white in color, oval and elongated in shape, and are laid either in the soil, leaf litter, or in rotting wood. The oviposition site is chosen carefully by the female, depending upon microcli- matic factors such as shadow, relative humidity, and the availability of prey (Brandmayr and ZettoBrandmayr 1979; Tréfás and van Lenteren 2008). Oviposition ranges from 30 to 600 eggs in a female beetle's total life span, with fecundity largely influenced by adult diet (Fawki and Toft 2005; Jørgensen and Toft 1997; Wallin et al. 1992) and body size (Juliano 1985).

A typical larva is a free-moving campodeiform (elongated, flattened, and active) with long thoracic legs. It has mandibles, antennae, and bears fixed urgomorphi (paired horn-like structures at posterior tip of abdomen of larvae and pupae) (Crowson 1981). Larvae usually undergo three larval instars, except in a few genera such as species of Amara and Harpalus, which only undergo two instars (Lövei and Sunderland 1996). Pupation occurs in a specially constructed pupal chamber in the soil. Adult carabids have a wedge-shaped body that allows movement under cracks and crevices and beneath litter (Evans 1977, 1986; Evans and Forsythe 1985; Forsythe 1981, 1983, 1991). A carabid head has prominent mandibles, palps, and filliform antennae. The antennal cleaning organ on the protibia facilitates chemosensory reception among carabids (Evans 1994). Striated elytra provide protection to the wings and abdomen, preventing water loss from the body (Hammond 1979). Further, carabids possess long slender legs that help them in running, digging, burrowing, climbing, and swimming (Evans 1977, 1986; Lindroth 1961-1969; Thiele 1977). In general, temperate ground beetles are univoltine. However, under harsh conditions some species can survive up to 4 yr (Lövei and Sunderland 1996).

Ground Beetles and Seed Diets. Carabids are generally polyphagous and feeding habits vary from carnivory to omnivory to granivory (Hurka and Jarosik 2001). Forbes (1883) first reported the granivorous behavior of carabid beetles, but based on gut dissections, Zhavoronkova (1969) classified carabids into three categories: strict predators (obligate zoophages), predominant zoophages, and predominant phytophages, with members of the latter two categories being the highest consumers of seed material. Larochelle (1990) published the food range of 1,054 carabid and cicindelid species: 74\% species were exclusively carnivorous, $8 \%$ were phytophagous, and 20\% were omnivorous. However, many of these studies were laboratory-based and overestimated the predatory habits of carabid species (Lövei and Sunderland 1996). The general 
assumption regarding the carnivorous nature of many carabid species is exaggerated (Lindroth 1992). In fact, Lindroth (1992) found that about $35 \%$ of the species he studied exhibited omnivorous feeding habits.

Within plant-feeding carabids, two groups are mainly distinguished: the first utilizes green plant parts and fruits for supplementing beetle water requirements whereas the second group, called "spermophagus," prefers to feed on seeds (ZettoBrandmayr 1990). The two tribes with the most granivorous members include the Harpalini (Goldschmidt and Toft 1997; Lundgren 2009; Saska 2005; Thiele 1977;), and Zabrini (Lundgren 2009; Saska 2005; Thiele 1977; Tooley and Brust 2002). Species of Amara, Anisodactylus, Harpalus, Ophonus, Poecilus, Pterostichus, and Stelophonus have demonstrated mainly granivorous habits (Lundgren 2009). However, seed feeding is not limited to the granivorous species. Many species generally considered highly carnivorous, including Bembidion quadrimaculatum (L.), Cyclotrachelus alternans (Casey), Elaphropus sp., Poecilus lucublandus (Say), Poecilus versicolor (Sturm), and Pterostichus permundus (Say) have been documented in recent molecular studies to feed on weed seeds (Lundgren et al. 2013). Evidently the diet requirements of many carabid species have not been fully understood and the potential role of several such species in weed seed feeding is perhaps underestimated. Further, most studies have reported weed seed consumption by adult carabids only. Larvae can also contribute substantially to weed seed removal, which is not well documented (Saska 2005), except for a few species such as Amara similata (Gylenhall) (Fawki and Toft 2005; Jørgensen and Toft 1997). Understanding larval feeding habits is complicated by their subterranean habits, and the complexities associated with laboratory rearing (Lövei and Sunderland 1996). Within carabid groups, there are significant variations in larval feeding habits. In an evolutionary context, granivory is an apomorphic character in the larvae of Carabidae and evolved independently in several groups of the family (Hůrka and Jarosik 2003; Klimes and Saska 2010; Saska and Jarosik 2001; Zetto-Brandmayr 1990 ), whereas carnivory is considered plesiomorphic (Hưrka 1996).

Within the Carabidae, granivory, as a derived character, occurs in relatively few species. Larvae of the granivorous genus Amara were considered primarily carnivorous (Luff 1993), until Thompson (1979) and Hưrka (1998) demonstrated that Amara larvae could be reared on a diet of oat flakes. Recent evidence suggests that larvae of Amara could be granivorous (Fawki and Toft 2005; Jørgensen and Toft 1997; Klimes and Saska 2010), or omnivorous (Hůrka and Jarosik 2001, 2003; Saska 2005). Larvae of species from genera Ditomus, Ophonus, and Harpalus have also been reported to be primarily granivorous (Briggs 1965; Kirk 1972; Zetto-Brandmayr 1990). Larvae of Ophonus puncticeps (Stephens) and O. ardosiacus (Lutshnik) are exclusive seed feeders and generally consume umbelliferous seeds (Zetto-Brandmayr 1976, 1983). Despite variations in extent to which granivory has evolved among larval groups, their role in weed seed consumption is important and has implications for weed management.

Adaptations to Granivory. Seed-feeding carabids have several behavioral, morphological, and physiological adaptations for granivory. For example, seed-caching behavior is prominently observed in the adults of Ditomus spp. (Schremmer 1960) and in larvae of Harpalus and Ophonus species (Hartke et al. 1998; Kirk 1972; Luff 1980; Zetto-Brandmayr 1983). However, size and depth of these burrows are species-specific and can vary according to larval stage. For example, first- and second-instars can burrow 10 to $13 \mathrm{~cm}$ in the soil (Alcock 1976; Hartke et al. 1998; Luff 1980), but the third-instars can burrow up to $17 \mathrm{~cm}$ (Luff 1980). Burrowing habits help to protect the larvae from predators and other natural enemies and also help to maintain better conditions for growth, such as regulating humidity and avoidance of water loss. The seeds cached can be maintained in good condition for a long time (Tooley and Brust 2002).

Apart from seed caching, another behavioral adaptation is climbing on plants. Sasakawa (2010a) observed that several carabid species belonging to the genera Amara and Harpalus climb on weeds and feed on flowers and seeds. For instance, Amara gigantea (Motschulsky) climbed preferentially on plants of Japanese hops [Humulus japonicus (Sieb. \& Zucc.)]. The climbing and foraging behavior was observed mainly in females, and females consumed more seeds than males (Saska et al. 2010). Males climbed on plants primarily for copulation rather than for foraging or seed feeding.

To crush the hard seeds, larvae of Amara have developed broad and triangular mandibles with the presence of a subapical tooth in some species (Klimes and Saska 2010). In contrast, larvae of Harpalus possess stout mandibles (Luff 1993), and 
the adults of these genera possess broad mandibles (Forbes 1883; Forsythe 1983; Zetto-Brandmayr et al. 1998). Acorn and Ball (1991) studied mouth parts of adult granivorous carabids, and noted that these beetles possess robust mandibles with highly modified structures. For example, the terebral ridge of the mandibles is more sinuate in occlusal aspect to give additional strength to the mandibles. Similarly, a chisel-shaped incisor region provides vertical shear, and the retinacular region is wellmodified in a way such that the ridges of retinaculum form a compact basin for the production of the bolus of the chewed food.

Digestion of solid plant material is facilitated by the evolution of sclerotized structures in the adult proventriculus (Evans and Forsythe 1985). Microbial communities in the gut play an important role in digestion of plant-based food in omnivorous insects (Campbell 1989; Jones 1984). Knowledge of the physiological adaptations for digestion of seed material in carabid beetles is currently limited. The presence of endosymbiont communities in the gut of Harpalus pensylvanicus (De Geer) is known, and they possibly have a role in facilitating digestion of seed material (Lundgren and Lehman 2010).

Importance of Seed in the Carabid Life Cycle. Seed is a more nutritious food source for granivores compared to any other plant structure due to its high protein content and nitrogen levels (Bewley and Black 1994; Crawley 2000; Lundgren 2009). Seeds in the diet can influence female fecundity, survival of preimaginal stages, overall growth and developmental rate (Saska 2005; Saska and Jarosik 2001), and larval survival (Fawki and Toft 2005; Sasakawa 2010b).

Species-specific differences exist in the importance of seed vs. animal food in the diet of carabids. For instance, larvae of Ophonus spp. feed exclusively on seeds, and supplementing their diet with animal food affects their survival and development (ZettoBrandmayr 1990). Larvae of Harpalus honestus (Duftschmid) developed faster when fed solely with seeds of dandelion (Taraxacum officinale F.H.Wigg.) compared with animal-based diets (Zetto-Brandmayr 1990). By contrast, larval developmental and survival rates were higher for the omnivorous species, Amara aenea De Geer (Hůrka and Jarosik 2003), and Amara convexiuscula Marsham (Saska 2005) for a seed- and animal-based diet mixture vs. a pure seed-based diet. Jørgensen and Toft (1997) determined that larval survival and development of Amara similata were higher on a mixed seed-based diet than on seeds mixed with an animal diet. Likewise, adding animal components such as earthworms or slugs reduced the chances of larval survival for Amara similata, and larvae performed better on a pure seed diet (Fawki and Toft 2005).

Food quality can also affect female fecundity in carabids. For example, Amara similata females laid more eggs when fed a mixed seed diet or when an animal-based diet was supplemented with seeds. The species of weed seed can significantly influence life parameters in granivorous carabids. Females of Amara similata fed seeds of scentless chamomile, Tripleurospermum perforatum (Mérat) M. Lainz and dandelion, Taraxacum sp. had higher fecundities than those that fed seeds of annual bluegrass, Poa annua L. (Jørgensen and Toft 1997). Larvae responded differently than adults and their survival rate was highest on smaller seeds of $C$. bursa-pastor is over the larger seeds of $T$. perforatum and Taraxacum sp. This was probably due to larger seed size of $T$. perforatum and Taraxacum sp., which are difficult for the first instars to consume (Jørgensen and Toft 1997). Thus, nutritional preference depends on the seed species and animal prey involved, which optimize nutritional gain required to complete the physiological process of granivorous species (Lundgren 2009).

Weed Seed Preferences of Carabids. Carabids can exhibit specific preferences for seeds of certain weed species. Such preferences are influenced by carabid species as well as seed characteristics. Important factors determining weed seed consumption are the size of the seed consumer and the size of the seed, both of which influence seed consumption rates (Brown et al. 1979; Brust and House 1988; Hartke et al. 1998).

Preferences of weed seed consumers could have impacts on weed communities. Preferences for specific weed seeds could lead to changes in the population dynamics of the preferred weed species and also of the weed community in general. Brust (1994) observed that under greenhouse conditions, carabid species preferred seeds of dicot over monocot species, thus altering the relative yield of broadleaf weeds compared to grassy weeds. Such a preference and the resulting yield losses would create a competitive advantage for the nonpreferred over preferred weed, thus influencing the population composition and community structure of weed species under field conditions. On the contrary, some other studies reported that monocot weeds 
were preferred over the broadleaf weeds (Saska 2008b; Heggenstaller et al. 2006). Davis et al. (2013) determined that variation in long-term seed consumption is largely determined by the weed species. Hence, if a seed-feeding species exhibits a strong preference for an economically important weed species in a particular agroecosystem, it might play an important role in management of that weed population.

Carabid beetle body size is among the major determinants of weed seed preferences. Honek et al. (2003, 2007, 2011) experimented with adults of several carabid species and found that the preference for the seed depended on carabid body size.

The abundances of granivorous and omnivorous species in a given agroecosystem also determine weed seed consumption. Furthermore, the composition of species assemblages in terms of carabid body size would ultimately influence seed preferences under field conditions. Preferences of largebodied species such as $H$. pensylvanicus for large weed seeds are thus most likely to influence weed communities producing relatively large seeds. Such preferences can favor other weed species if the composition of the carabid fauna is dominated by one or a few species with highly specific preferences. However, size-based seed preferences can also facilitate co-existence of different granivorous carabid species and reduce intraguild competition (Lundgren 2009). Such reduced intraguild competition in the presence of small- and large-bodied carabids has been documented under field conditions. With few exceptions, large carabids preferred larger seeds and vice versa. For example, large carabids are known to feed on dandelion seeds of large size whereas the smaller carabids prefer smaller dandelion seeds (Honek et al. 2011). Although seed consumption is positively associated with the body size of the granivorous carabids (Honek et al. 2006), the rates of seed consumption among large-sized carabids can vary. For example, individual adults of species such as Pseudophonus rufipes (De Geer) have been reported to consume 10 to 12 seeds $\mathrm{d}^{-1}$ of canola, whereas Pterostichus melanarius (Illiger) consumed 2 to 8 seeds $\mathrm{d}^{-1}$ (Koprdová et al. 2012). However, several factors including, and not limited to, the diet of omnivorous species, physical state of seed (exhumed, imbibed vs. dry), and taxonomic preferences for seed consumption might bring about such differences in observed rates of weed seed consumption among bigger carabid groups (Koprdová et al. 2012). In fact, Gaines and Gratton (2010) determined under field condi- tions that small carabid species consumed seeds that were smaller (3.26 $\mathrm{mm}$ diam), whereas large carabid species consumed seeds that were larger $(4 \mathrm{~mm}$ diam). Prior research indicates that there is a certain seed size beyond which the seeds are unacceptable (Lundgren and Rosentrater 2007). However, once this size limit is set, other seed traits govern carabid seed preferences. These other traits include seed coat hardness, seed density, nutritional quality, or other morphological traits. Such seed characters are seed defensive traits (Lundgren 2009), and are the mechanisms utilized by seeds to deter predation. For example, a hard seed coat restricts granivory because the granivore needs to invest substantial energy to break the seed coat and reach the endosperm (Brust and House 1988; Carmona et al. 1999; Kremer and Spencer 1989; Tooley and Brust 2002). Preference for softer and smaller seeds of redroot pigweed (Amaranthus retroflexus L.) and giant foxtail (Setaria faberi Herrm.) over hardcoated and large seeds such as velvet leaf, Abutilon theophrasti Medik. were attributed both to the physical properties of the seed coat and to seed size (White et al. 2007). Nevertheless, certain carabid species prefer seeds with hard seed coats over those with soft seed coats. For example, $H$. pensylvanicus preferred smaller, tough seeds with hard seed coats whereas Anisodactylus sanctaecrucis (Fabricius) preferred seeds that were hard internally (Lundgren and Rosentrater 2007). Although some earlier studies indicate that hard seed coats restrict granivory (Cardina et al. 1996; Pausch and Pausch 1980; Ready and Vinson 1995), this cannot be generalized for all seed types because the strength of, and adaptations possessed by, a particular carabid species determine seed preferences. Similarly, seeds with external appendages and projections offer mechanical resistance to predation. Further, chemical seed defenses include concentrated secondary metabolites such as alkaloids, lectins, phenolic compounds, and gluosinolates (Lundgren 2009).

The origin of weed species can also affect predation. Under a choice scenario, carabid beetles from the Czech Republic preferred dandelion seeds from the Czech Republic over the seeds originating from Italy (Honek et al. 2011). However, the information on population preferences and the mechanisms involved in such preferences is currently limited.

Nutritional quality of the seed is also an important criterion determining seed preferences (Crist and McMohan 1992; Inouye 1980). However, few studies have explored the effects of 
nutritional quality on carabid weed seed preferences. The nutritive value of seeds can directly affect life history parameters of the consumer, and nutritional gains and the associated advantages can vary among seed types, influencing the performance of the granivore. Higher fecundity and larval growth rates of Harpalus rufipes (DeGeer) on the seeds of common lambsquarters (Chenopodium album L.) than those of other cereals and rye grass are indicative of nutritional advantages associated with common lambsquarters seeds. As a consequence, larvae of $H$. rufipes tended to aggregate in field patches with high common lambsquarters density (Briggs 1965). This demonstrates that nutritional quality is not only a determinant of seed preferences but can also determine field dynamics and foraging behavior of seed consumers.

It is not only carabid adults that show specific weed seed preferences because even the larvae can prefer one seed type over another. These preferences are mainly expressed by the early larval instars and might be governed by morphological traits such as the size of the larval head capsule. For example, first-instar larvae of Amara similata fed exclusively on seeds of common chickweed (Paarmann et al. 2006) and shepherd's purse (Klimes and Saska 2010), whereas the later instars had generalist feeding habits that lacked discrete preferences. First-instar larvae of the generalist species, Amara aenea, had more difficulty in crushing the hard seed coat of dandelion compared with the late instars, which supports the idea that morphological constraints are an important factor in the seed preferences of granivores (Paarmann et al. 2006). Larvae with burrowing habits and seed-caching strategies also demonstrate specific seed preferences (Alcock 1976). For instance, larvae of $H$. pensylvanicus and Harpalus eraticus Say mainly prefer foxtail seeds for storing in a seed cache (Kirk 1972). It is not clear whether factors such as nonperishability over long storage durations might influence the preference of carabids for specific weeds.

Finally, mobility of seed consumers such as carabids has been considered to influence rates of weed seed predation (Cromar et al. 1999). Adults of Carabidae are highly mobile, but the larvae are relatively less mobile than adults; in some species, adults cache the seeds as a part of maternal care to provide seeds to immature stages (Lundgren 2009). However, not much is reported on how the mobility affects the seed tracking behavior. For example, it is not documented whether the beetles can track seeds away from their habitat efficiently, and how far they can move in tracking seed sources. Previous studies have reported that carabids did not respond specifically to weed density manipulations, which suggests that they do not respond to stimuli such as seed density (Westerman et al. 2008).

\section{Potential of Granivorous Carabid Species in the Biological Control of Weeds}

Weed seed banks are major contributors to the widespread development of weed communities in agricultural fields (Fox et al. 2013), and weed management strategies need to focus on controlling the seeds entering the soil seed bank (Fox et al. 2013). In this context, weed seed consumption by invertebrates plays an important role. There have been some indications that interception of seeds entering the weed seed bank can be more affected by the activity of ground beetles than other causes, such as natural aging of seeds or seed decay (Bohan et al. 2011; Westerman et al. 2003b).

In general, levels of weed seed predation in the field can vary (Table 1), and specific weed seed consumption rates are difficult to quantify as even conspecifics can differ in terms of seed consumption. In some cases, predation rates can be as low as $4 \% \mathrm{~d}^{-1}$ (Brust and House 1988) but in other studies, carabids can consume the majority of seeds in a system, sometimes consuming $70 \%$ of all seeds in a given season (Harrison et al. 2003). Such variations can be attributed to agricultural management activities (Brust and House 1988; Hatten et al. 2007; Menalled et al. 2007), seasonal population fluctuations of beetles (Honek et al. 2006), phenological changes in the carabid life cycle (e.g., overwintering stages, breeding season, dispersal etc.), biotic factors such as high level trophic interactions (Davis and Raghu 2010), the presence of alternative food sources (Frank et al. 2010, 2011), abiotic factors such as temperature (Saska et al. 2010), seed distribution patterns on the soil surface (Noroozi et al. 2012), and the method of seed exposure in the field (Saska et al. 2014; Shuler et al. 2008).

Under greenhouse conditions, a reduction in seed number of common lambsquarters and redroot pigweed by 56 and 63\%, respectively, has been reported for eight carabids species belonging to Amara, Anisodactylus, Harpalus, and Stenolophus (Brust 1994). Likewise, carabid species such as Harpalus affinis Schrank and Pseudophonus rufipes have been shown to feed on as many as 120 seeds of Canada thistle [Cirsium arvense (L.) Scop.] in a 5-d 


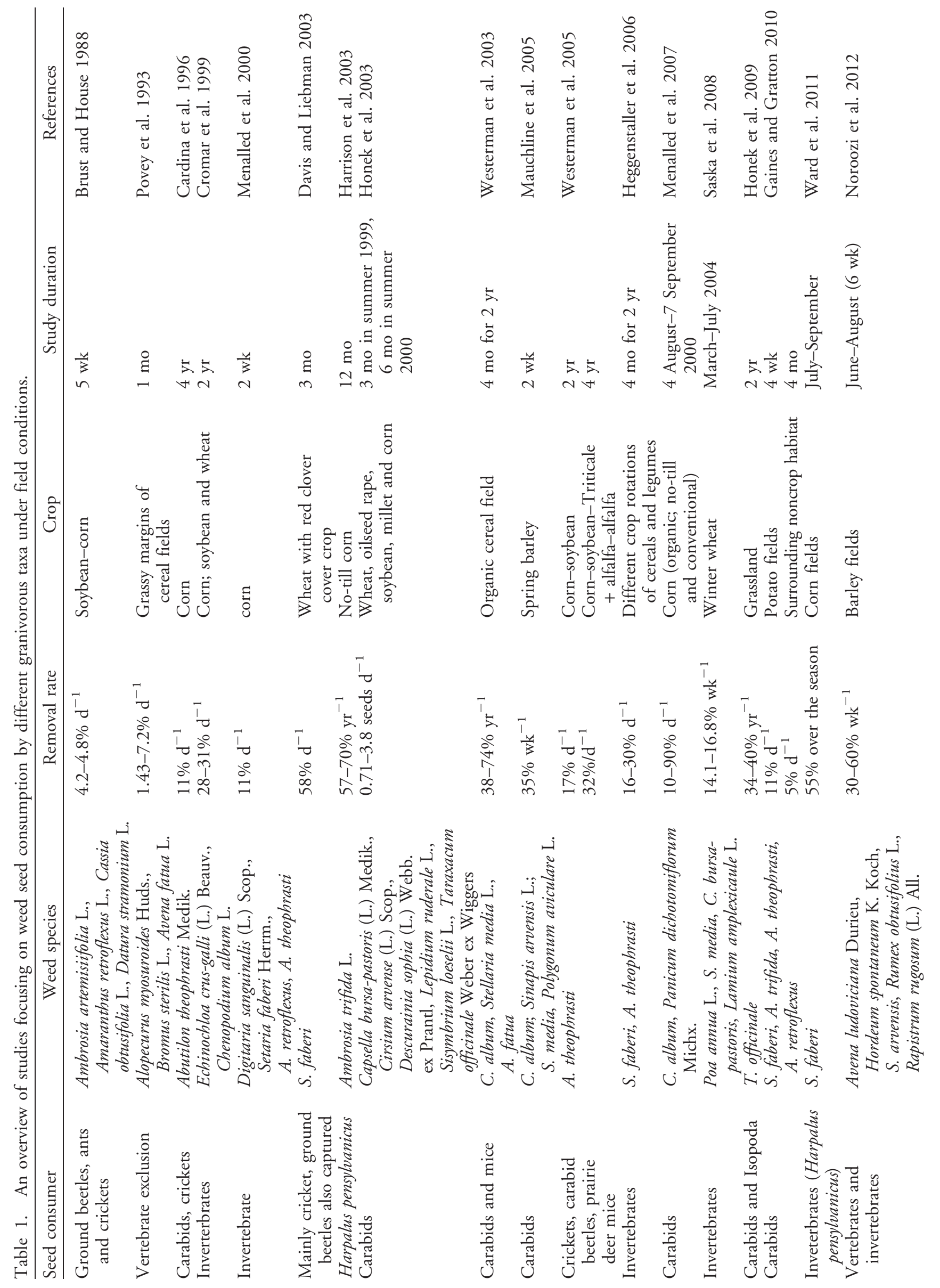

362 - Weed Science 63, April-June 2015 


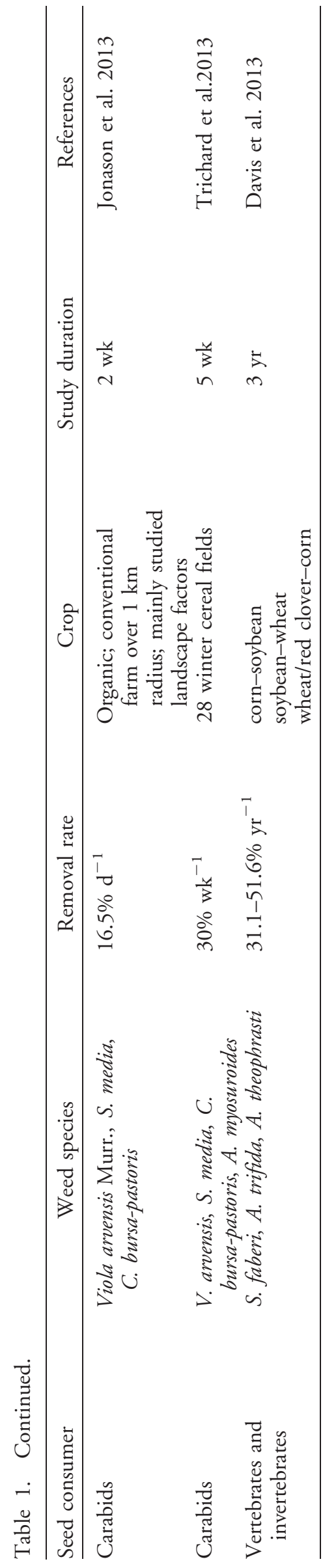

period (Martinkova et al. 2006). Similarly, Harpalus spp. have been reported as the dominant weed seed consumers in several field experiments (Brust and House 1988). In Indiana, $H$. pensylvanicus was a major seed consumer on 12 weed species (Lund and Turpin 1977), whereas Amara spp. and Harpalus spp. have been shown to contribute to more than $70 \%$ of weed seed consumption in other studies (Table 1) (Mauchline et al. 2005).

Although laboratory studies demonstrate the weed seed-feeding potential of carabids, the relationship between seed consumption rates and the activity-density (numbers captured $\operatorname{trap}^{-1}$ day $^{-1}$ ) of granivorous ground beetles has proven to be ambiguous under field conditions. Several studies have observed a positive relationship (Gaines and Gratton 2010; Honek et al. 2003, 2005; Jonason et al. 2013; Menalled et al. 2007; Trichard et al. 2013), whereas other studies have shown a lack of spatio-temporal association between the two factors (Mauchline 2005; Saska et al. 2008). A lack of relationship between activity-density and seed consumption activity might be attributed to the method of sampling (Lundgren et al. 2013), and site-specific variations in rates and activity of seed consumption (Davis et al. 2013). For example, most studies used pitfall traps to sample carabid beetles, but these are known to be biased towards the preferential capture of large, surface-active species (Arneberg and Andersen 2003; Spence and Niemelä 1994). The activity-density of carabid beetles trapped in pitfall traps fluctuates as a result of climatic factors (mainly temperature), which should be considered (Saska et al. 2013). Hence, interrelations between activity-density and carabid weed seed consumption should be interpreted with caution and with consideration, given to biases that can skew estimations. Despite this, pitfall trapping is a relatively common method used in most studies due to the relative ease in handling the traps, and the efficiency in trapping carabid beetles. Activitydensity as an indicator of carabid abundance alone might not, however, be the best predictor of carabid weed seed-consumption activity.

Many of the studies reported here measured surface weed seed predation; only one study has examined the actual relationship between carabid activity-density and its effect on seeds deeper within the soil seed bank. A study by Bohan et al. (2011) examined the relationship between activity-density of carabids and the seed bank in spring maize (Zea mays L.) and winter oilseed rape in fields across the United Kingdom. The results showed that the 
granivorous and omnivorous carabid species are efficient in managing seed banks of monocot weed seeds, and omnivorous Pterostichus melanarius had a density-dependent response to monocot weed seed banks. In addition, the activity-density of three Pterostichus spp. was efficient in consuming postdispersal seeds and reduced the number of seeds entering the soil seed bank.

Synchronization between the weed seed availability on the ground surface and phenologies of carabid species is also important for effective weed seed removal (Mauchline et al. 2005; Westerman et al. 2012). Several carabid beetles such as $H$. pensylvanicus and Pterostichus melanarius are autumn-breeding, whereas species such as Amara littoralis (Mannerheim) are spring breeders. The seasonal phenologies of these species would thus influence weed seed consumption.

Many carabid species that feed on weed seeds are omnivorous, and the presence of alternate food sources could decrease seed feeding over the growing season. This omnivorous behavior can lead to variable seed consumption; omnivory is higher earlier in the season than later due to the high availability of alternate prey (Marino et al. 2005; Mauchline et al. 2005). Trichard et al. (2013) determined that the weed seed consumption rate was positively related to the diversity of granivorous species and negatively related to the diversity of omnivorous species. This association might be due to variable preferences of some omnivorous species between animal and plant food sources. In another study, the omnivorous carabid beetles responded positively to seed subsidies in the field (Frank et al. 2011). Therefore, seed consumption is dependent on the availability of alternate resources, carabid species preferences (granivory vs. omnivory), and any potential deterrents utilized by the seed (Lundgren 2009).

Seed burial is a major factor hindering postdispersal seed consumption (Chambers and McMahon 1994; Crawley 2000). Several processes, including tillage, the development of cracks and pores due to changes in soil physical properties, and the activities of terrestrial fauna (burrowing, caching) can result in seed burial at a depth where they are no longer available to surface activepredators (Chambers and MacMahon 1994; Westerman et al. 2006).

Carabid species differ in their ability to consume seeds that are buried at different depths (Klimes and Saska 2010). Some species such as Amara aenea and Anisodactylus sanctaecrucis showed reduced seed consumption as the depth of the seed burial increased. In contrast, predation by $H$. pensylvanicus remained unaffected by seed burial depth. H. rufipes preferred wild mustard (Sinapis arvensis L.) seeds dispersed on the ground compared to buried or half-buried seeds; both the seed consumption rates and efficiency were affected by seed burial (Harrison and Gallandt 2012). Despite such differences in weed seed consumption, the role of seed-feeding carabid species in weed seed removal and soil seed bank management is important, and need to be investigated further.

Earlier studies have reported that weed seed consumption can be density-independent (Brust and House 1988), inversely density-dependent (Cardina et al. 1996), or positively densitydependent (Cromar et al. 1999). Weed populations are patchy under field conditions and this spatial aggregation plays a role in weed dispersal (Cousens et al. 2006; Rew et al. 1996). This can be positive because density-dependent seed consumption in weed patches is beneficial in terms of weed management. For example, if the rate of seed consumption increases with increasing seed density in patches, it can significantly limit future weed dispersal and persistence (Cousens et al. 2006; Lundgren 2009). Two limitations exist, however: (1) density-dependent weed seed consumption is more prominent in ants than in carabids; and (2) absolute seed density alone does not determine weed seed removal by carabids, although they prefer aggregated seed patches (Marino et al. 2005; Noroozi et al. 2012). As a result, higher weed seed removal rates were measured in fields with highly aggregated seed distributions than when seeds were available in high densities (Marino et al. 2005; Noroozi et al. 2012).

Seasonality in weed seed availability also determines seed consumption behavior. Westerman et al. (2008) determined there was more positive densitydependent seed consumption late in the season than earlier in the season. However, density-dependent seed consumption patterns cannot be established as a norm in the case of carabid species because seed consumption is a result of several functionally diverse granivorous communities acting variably at different spatial and temporal scales (Hulme 1998; Marino et al. 2005). High seed density can result in satiation and lead to an inverse density-dependent response (Janzen 1971), and under such circumstances biological control might not be an effective strategy (Lundgren 2009). Even under laboratory conditions, carabids showed early satiation at high 
seed densities that resulted in reduced seed consumption (Honek et al. 2003, 2006). This suggests that when seeds are available in excess of what seed-consuming carabids can eat, there is a gradual decline in rates of seed consumption once that satiation level has been reached (Lundgren 2009). Hence, high seed availability might not always coincide with high seed-removal rates. However, attainment of satiation largely depends on the time of year (Westerman et al. 2008), the overall hunger level of consumers, and the community composition. Synchronization of carabid activity with seed production and dispersion patterns can help carabid communities maintain their seed consumption activity, and carabid communities are frequently well-synchronized with weed seed production patterns (Lundgren 2009). Consequently, higher satiation patterns and a subsequent decline in carabid weed consumption rates are often documented in late fall (Davis and Raghu 2010; Westerman et al. 2008).

\section{Factors Affecting Weed Seed Consumption under Field Conditions}

Several factors influence carabid weed seed consumers and their seed consumption activity either directly or indirectly. An understanding of these factors is important to conserve seed consumer fauna and increase seed consumption activity in order to enhance weed management. Below, we present an account of the major factors that affect weed seed consumption under field conditions.

Agricultural Management Practices. Because of their epigeal habit, carabid activity in agroecosystems is affected by agricultural management practices such as crop species, cultivation intensity, and crop diversification. Factors such as species habitat preference (Thomas et al. 1997), soil cultivation pattern (Cárcamo et al. 1995; Holliday and Hagley 1984; Tyler and Ellis 1979), cropping system (Blubaugh et al. 2011; Booij and Noorlander 1992; Cárcamo et al. 1995; Carmona and Landis 1999; Dritschilo and Wanner 1980; Kromp 1989, 1990), and the use of pesticides (Lee et al. 2001; Marko and Kadar 2005) can influence carabid activity. Agricultural management practices influence characteristics of the habitats for different carabid species by altering soil physical properties. For example, soil microclimate, sod layer, and crop stand characterestics influence carabid life history parameters such as overwintering. A good sod layer maintains aeration and serves as an amenable site for overwintering because it maintains favorable temperature and microclimate (Desender et al. 1981) compared to compact sod with poor aeration. However, the influence of disturbance caused by cropping practices depends on species habitat requirements and behavior. Here we have focused on important agricultural management practices that influence the activity of seed-consuming carabid groups. The practices we have emphasized include tillage, crop diversification, and other management practices such as pest management, and their direct and indirect influences on carabid activity.

Tillage. Tillage influences carabid abundance because of the direct mortality it causes to carabid populations (Fadl et al. 1996). It also indirectly influences microclimate and habitat structure (Stinner and House 1990). Tillage operations influence both the distribution of weed seeds and the depth to which they are buried. Also, changes caused to vegetation bring about differences in microhabitat conditions by altering factors such as humidity and vegetation cover (Shearin et al. 2007). In general, seed-feeding species tend to prefer undisturbed fields (Hatten et al. 2007; Menalled et al. 2007; Trichard et al. 2013).

However, the effects of tillage on carabid populations can vary among carabid species. One of the important factors causing this variation is synchronization between timing of tillage operations and the presence of sensitive life stages of carabid species. The autumn-breeding Pterostichus melanarius overwinters as a larva in the soil, and hence spring conventional tillage could negatively affect its populations (Cárcamo 1995; Fadl 1996; Hatten et al. 2007; Lalonde et al. 2012; Shearin et al. 2007). The extent to which a carabid species is affected by tillage is also determined by species habitat preferences and habits. For example, the larvae of $H$. rufipes overwinter deep in the soil at a depth of about $45 \mathrm{~cm}$ (Briggs 1965; Speight and Lawton 1976), a habit that can help them to escape the deleterious effects on their populations of tillage operations in early spring (Baguette and Hance 1997; Shearin et al. 2008). Tillage performed at a shallow depth is therefore less likely to damage the larvae and pupae of $H$. rufipes. In contrast, the eggs, adults and neonate larvae of this species are most prone to tillage operations performed in late spring because they are present in the upper soil layer and exposed to tillage operations directly. Hence, how a 
particular operation is likely to affect a given carabid species depends upon the overlap of agricultural operations with phenological parameters and species characters.

The equipment used for tillage operations determines the extent of soil disturbance and its ultimate effect on carabid populations. Studies indicate that soil disturbance and subsequent damage to granivorous beetles was lower when a chisel plow was used under a minimum tillage regime, compared to the disturbance caused by a mouldboard plow and rotary hoe (Shearin et al. 2007). Prior studies indicated that seed-feeding carabid species thrive in undisturbed habitats. Based on these observations, one might assume that seed consumption rates could be higher under zero tillage conditions. However, earlier studies determined that the impact of disturbance on seed distribution and subsequent seed consumption can be ambiguous (Cromar et al. 1999; Menalled et al. 2007; Trichard et al. 2013). Menalled et al. (2007) reported that both the activity-density of seed-feeding species and the rate of seed predation were higher in zero tillage fields than in conventionally tilled fields. Contrary to this, Cromar et al. (1999) reported that weed seed consumption rates were higher in fields subjected to a zero tillage regime as well as those tilled with a mouldboard plow, compared with those fields that were tilled with a chisel plow. This indicates that not only does the type of tillage influence seed consumption, but so too does the equipment used for tillage.

Further, zero tillage regimes create undisturbed conditions, which sustain high arthropod diversity (House and Parmelee 1985). This also ensures higher prey availability, and thus, alternate prey resources for invertebrate predators, including ground beetles. This ultimately influences the seed consumption behavior of seed predators (Cardina et al. 1996). Due to availability of alternate prey sources, variable weed seed consumption rates can be observed. On the contrary, fields subjected to intensive tillage operations (for example, using a mouldboard plow) can cause extensive disturbance, destroy sheltered habitats for various arthropod species, and hence negatively affect arthropod biodiversity (House and Parmelee 1985; Stinner et al. 1988). As a consequence, the availability of alternate food resources is reduced and higher rates of seed predation are measured (Cromar et al. 1999). Given the above observations, the interrelations among tillage, carabid population dynamics, and weed seed consumption are obviously complex (Shearin et al. 2007).
Cropping Diversity. Diversity of carabid beetles under different cropping systems has been studied extensively. Studies have usually demonstrated that carabid populations are increased under diversified cropping systems (Armstrong and McKinlay 1997; Kromp 1999; Tukarhiwa and Coaker 1982) because of increased immigration rates, longer residence times in patches, and decreased emigration from intercropped plots (Cárcamo and Spence 1994; Perfecto et al. 1986). However, the impact of these strategies in promoting thriving granivorous carabid taxa depends largely on the crop type, the crop phenology, and the habitat requirement of the granivorous taxa present in that field. Previous results conclude that a cover crop and its residue can have a positive impact on predator communities by providing a favorable microhabitat, which protects them from extreme climatic conditions and provides for greater food resources (Carmona and Landis 1999; Manley 1996; Rivard 1966; Speight and Lawton 1976). Some carabid species, such as Bembidion spp., are xerophilous, preferring dry areas with sparse vegetation (Hummel et al. 2012), whereas some are hygrophilous, such as Pterostichus melanarius, which prefers a dense crop canopy and might benefit from cover crops such as clover (Trifolium spp.). Understanding interactions among major granivorous species from particular agroecosystems and their habitat requirements can help to conserve beneficial species. This can be achieved by maintaining suitable shelter areas and vegetation that can provide supplementary food resources and microhabitats for different species.

Among the abiotic conditions that support higher carabid faunas are soil temperature and relative humidity (Shearin et al. 2008). The type of crop grown significantly alters soil temperatures and humidity, and can influence carabid abundance and seed consumption. For example, a cover cropping system of oat (Avena sativa L.) and pea (Pisum sativum L.) in summer followed by a fall crop of winter rye (Secale cereale L.) and hairy vetch (Vicia villosa Roth) will lower soil temperature and increase relative humidity, thereby favoring the abundance of $H$. rufipes, compared to a system consisting of a fallow season followed by the cover crops of clover and oat (Shearin et al. 2008). Fallowing for one season relies on disturbance-based weed management and is most likely to impact carabid abundance and activity, thereby creating conditions that are less favorable than those created by suitable crop regimes.

The amount of vegetation cover varies with crop phenology, which in turn affects populations of 
granivorous taxa and the rate of seed removal under field conditions (Heggenstaller et al. 2006; Westerman et al. 2011). For example, higher seed removal rates in a phenologically late-maturing crop of sugar beet (Beta vulgaris L.) have been observed compared to early-maturing cereals (Westerman et al. 2011). This can be attributed to two factors: high activitydensity of granivorous taxa late in the season due to abundant vegetation cover in the late-maturing sugar beet field compared to cereals, as well as high temporal overlap between carabid activity and seed rain. This example demonstrates that diversifying cropping systems by incorporating crops with different phenologies can help to provide a long activity window for granivorous carabids to consume weed seeds. Similarly, weed cover and diversity can impact seed predation. Blubaugh et al. (2011) determined that weed cover conserves more omnivorous species that probably feed on weed seeds. Likewise, the activity-density of two major granivorous species in Pennsylvania [Amara aenea (De Geer)and $H$. pensylvanicus] was higher under a cover crop regime compared to a fallow and soybean [Glycine max (L.) Merr.] crop (Ward et al. 2011).

In a crop rotation, seed losses can vary over different phases of the rotation as a result of crop type, crop age, and weeds associated with specific crops. For example, in a crop rotation sequence of corn-soybean-triticale (Triticosecale spp.) + alfalfa (Medicago sativa L.)-alfalfa, seed losses for weeds such as velvetleaf (Abutilon theophrasti Medik) attributed to carabid activity were as high as $40 \%$ in the soybean phase but only $27 \%$ in the other phases due to the change in associated weeds and crop growth stages (Westerman et al. 2005). The predicted losses can reduce weed populations substantially, and any further seed loss would result in a significant decrease in weed species such as velvetleaf in these cropping systems (Westerman et al. 2005).

In a crop rotation, a preceding crop can significantly influence the activity-density of granivorous carabids in succeeding crops. For example, in a canola-corn crop rotation system, more species from the granivorous genus Amara were recorded than in corn monocrops (Bourassa et al. 2010). Availability of canola seeds lost during harvesting operations in the preceding season could have resulted in the high numbers of this granivorous genus (Bourassa et al. 2010).

Other Disturbances. Among other factors that can influence carabid activity, the use of chemicals for agricultural pest management can be an important factor, although the effects of pesticides in crop management on seed-consuming communities such as carabids have not been extensively investigated (O'Rourke et al. 2006). In general, the use of insecticides and fungicides has been considered to negatively affect carabid activity (Fielding et al. 2013; Trichard et al. 2013). Estimation of direct and indirect effects of insecticidal applications on carabid groups and their biological control services can be complicated by the scale of study, species dispersal patterns, and immigration of untreated individuals from surrounding areas (Holland and Luff 2000). Omnivorous species such as Pterostichus melanarius have been known to be affected by insecticide applications (Holland and Luff 2000), and are known to be susceptible to the organophosphate insecticides such as dimethoate (Holland et al. 2000). Some insecticides such as synthetic pyrethroids, which are considered less toxic to nontarget organisms, have been reported to cause sublethal toxicity among carabid species (Tooming et al. 2014).

The studies investigating effect of insecticides indicate insecticidal application negatively affects carabid population (Brown et al. 1983; Floate et al. 1989). Some studies indicate that the effects of insecticidal applications can be short-lived, and populations can recover in time (Holland 1998; Holland and Luff 2000). Factors such as species dispersal ability, availability of shelterbelts, and unsprayed buffer zones determine the ability of beneficial species to recover from insecticide applications and repopulate field areas (Holland and Luff 2000). Further, reduced dosage of field applications of insecticides and herbicides can help to maintain carabid activity (Navntoft et al. 2006). At reduced applications rates $(0.25$ of the recommended application rates) of herbicides and insecticides, a $25 \%$ increase in overall carabid activity has been documented in Europe; however, the activity of one species, Pterostichus spp., improved by $62 \%$ under these reduced rates (Navntoft et al. 2006). This underlines the importance of judicious applications of agricultural chemicals as it pertains to the conservation of beneficial insects such as those that consume weed seeds, and in particular, the ground beetles of the Carabidae family.

Timing of application of agrochemicals, particularly of insecticides, is critical in context of maintaining carabid populations. For example, nocturnal species are less exposed to insecticide applications (Navntoft et al. 2006). Synchronization 
of adult emergence with time of insecticide applications further determines susceptibility of adults to such applications. Adults of omnivorous species such as Pterostichus melanarius emerge in spring, which coincides with the timing of insecticidal applications, and this could result in higher susceptibility of teneral adults to various insecticides (Navntoft et al. 2006).

Typically, the application of herbicides and fungicides has few direct adverse effects, but herbicide applications indirectly influence carabid populations through reduced food availability and habitat suitability (Brust 1990; Holland and Luff 2000). Previous studies indicate a lack of acute or chronic toxicity effects of commonly used herbicides (atrazine, simazine, paraquat, and glyphosate) on carabid fauna (Brust 1990). However, indirect effects of herbicide applications can be particularly prominent for strictly granivorous members that rely on weed seeds as a food source. Moreover, changes in composition, weed density, and seed availability can affect their activity (Holland and Luff 2000). The extent of the effects of herbicide applications further depends on species habitat requirements. Species that prefer open habitats can disperse better and are less affected by herbicide applications compared to species such as Amara spp. that require weedy patches and cropped habitats (Holland and Luff 2000). For example, smaller carabids that show burrowing behavior have been reported to be less affected by herbicide applications (Brust 1990) compared to large carabids.

Negative effects of fungicides can be measured in the form of reduced diversity of carabid groups. Trichard et al. (2013) recorded a negative impact of fungicides used for disease management on the Shannon diversity indices of granivorous species, whereas insecticides negatively affected total seed predation rates and the activity-density of omnivorous species. However, very few studies have attempted to understand such effects. Thus, the scales at which local management practices are implemented determine the impact on weed seed consumption of carabids. Consequently, higher weed seed removal rates are observed under organic farming regimes that lack pesticides use (Diekotter et al. 2010).

Current knowledge of the effects of pest management strategies on carabids is limited to general carabid taxa. Very few studies have focused on how granivorous species and their activities are influenced by pest management regimes. Further research to elucidate such effects is needed to devise pest management strategies that can conserve populations of seed-feeding carabids, thereby enhancing seed consumption and biological weed management.

Landscape Characteristics. Very few studies have investigated the role of landscape characteristics on granivorous and omnivorous carabid communities. Local agricultural management practices substantially influence landscape characterestics, which in turn influence carabid activity (Trichard et al. 2013). Factors such as surrounding landscapes and the proportion of vegetation cover surrounding cropped areas are known to positively influence the activity of granivorous carabids (Trichard et al. 2013). Habitats surrounding agricultural fields largely determine insect biodiversity and the associated agriculture environmental services (AES) these species provide, although such effects are mainly measured on rather large spatial scales (Flohre et al. 2011). Complex habitats $(<20 \%$ arable land) are a source of shelter and food resources and are attractive to many arthropod species. As a result, higher immigration rates to such habitats from surrounding seminatural or simple landscapes are observed (Ricketts et al. 2008; Tscharntke et al. 2005). Habitat complexity can thus compensate for the impacts of local management practices on biodiversity and allied environmental services through species immigration from surrounding areas.

The impact of habitat complexity on carabid diversity can also vary with food guilds. Carnivorous and granivorous species are more sensitive to landscape simplification processes than are omnivorous species (Purtauf et al. 2005), and this can result from a decrease in perennial noncrop habitats surrounding field areas and the resulting shortage of specific food resources for strictly carnivorous or granivorous species. Further, simple landscapes lack structural heterogeneity, and the agricultural management practices in such landscapes can negatively affect carabid activity (Fischer et al. 2011; Tscharntke et al. 2005, 2012). This is mainly due to the effects of extensive crop management practices on immigration and emigration rates of species between fields and surrounding areas. However, the level of disturbance determines habitat heterogeneity and its ultimate effects on environmental services such as seed consumption. For example, intensively managed conventional fields in simple landscapes surrounded by less intensively managed organic fields are known to 
harbor high carabid diversity compared to organic fields surrounded by conventional fields (Diekotter et al. 2010).

The type of noncrop habitat is also important. For example, seed removal rates are higher in fields surrounded by temporary pastures than fields surrounded by permanent pastures and forest (Trichard et al. 2013). Temporary pastures are more likely to be dynamic in terms of crop associations and availability of food and shelter than permanent habitats. Similarly, granivorous taxa are more abundant in grassland and open agricultural habitats than in forest habitats (Vanbergen et al. 2010). However, effects of habitat complexity are locally specific and can range from having a very high effect to no effect at all on habitat complexity (Winquist et al. 2011). A study from Sweden determined that complex habitats did not play a role either in fostering populations of carabid beetles or in influencing seed consumption rates; instead, both were higher in a simple landscape with a greater proportion of arable crops (Jonason et al. 2013). Consequently, an understanding of species dynamics at a given landscape scale with reference to landscape characters is important.

Mortality from Natural Enemies and Predation. A detailed account of natural enemies of carabids and the defense mechanisms of carabids in response to predation has been provided by Brandmayr et al. 2009. The major sources of natural mortality in carabids are natural enemies and environmental abiotic factors (Lövei and Sunderland 1996). Among major predatory species feeding on carabids, the important groups include farm birds (Green 1984; Poulsen et al. 1998), and birds with nocturnal habits such as owls, bats, amphibians (including frogs and toads), lizards, and rodents (Brandmayr et al. 2009). Among invertebrate natural enemies are ants (Formicidae) that can prey on carabids and compete for habitat, robber flies (Asilidae), and some species of rove beetles (Staphylinidae) (Brandmayr et al. 2009). The levels and extent of natural predation have not been reported, and effects on seed predation services have not been quantified.

Effects of Climatic Factors on Weed Seed Consumption. Variations in population dynamics and rates of carabid seed consumption in relation to seasonal climatic changes are known, and factors such as temperature, relative humidity, precipitation, and wind speed can affect carabid population dynamics and activity (Davis and Raghu 2010; Saska et al. 2013). Climatic factors can influence seed consumption rates in several ways, including a reduction in seed traceability through seed burial (Westerman et al. 2009), or by altering the life cycle or life stages of carabids (Kotze et al. 2011). For example, ambient temperature beyond the optimum temperature range of 4 to $35 \mathrm{C}$ can hamper reproductive status, larval development (Kotze et al. 2011; Saska et al. 2010), and seed feeding behavior. Increased seed consumption patterns with respect to increased temperature is known in species such as $H$. affinis and Pseudophonus rufipes (Saska et al. 2010). Precipitation and relative humidity can affect egg maturation, larval development, and hibernation success, and therefore are also critical factors determining population dynamics (Kotze et al. 2011) and seed removal (Lundgren et al. 2006).

\section{Future Research}

Given the intensive nature of crop cultivation and crop management practices in modern agriculture and their negative consequences on the ecosystem biodiversity, implementation of biological control of weeds using arthropods such as carabids can be challenging. However, an integrated weed management approach that incorporates agronomic practices that favor conservation of beneficial bioagents such as carabids can improve ecological services such as weed seed consumption. The studies reviewed here indicate that practices such as reduced tillage, habitat diversification, and judicious use of agrochemicals might have potential implications for enhancing granivory in agroecosystems. In a weed management context, it is important to acknowledge the fact that bioagents such as carabids cannot eliminate all the seed stock in a given area (Menalled et al. 2000a). However, their activity brings about substantial reduction in net seed stocks in seed banks over time, and biological control cannot be considered a stand-alone approach for weed management but should be integrated as an effective tool in harmony with other weed management practices (Lundgren 2009). A broader understanding of interactions between agroecosystem processes, disturbances, and the ecology of different carabid groups is essential to estimate the extent to which services such as granivory can be used to manage weed seeds. The studies reported here cover trends observed in carabid granivory in diverse regions, climates, and agroecosystems consisting of 
diverse carabid assemblages. Hence, the observed trends should be interpreted with caution. For effective weed management, studying long term seed consumption processes in different agroecosystems and regions might help to develop a better understanding of the patterns and factors governing such services. This can help to develop a long-term strategy to improve weed consumption services (for example, thorough planning of appropriate crop rotations, crop types, management of surrounding habitats etc.).

Although the role of carabids as "generalist" predators of arthropod pests is well-recognized, several knowledge gaps exist in understanding their role as biological control agents of weeds. Overall, laboratory studies have demonstrated the importance of carabid size, seed size ratios, (Honek et al. 2003, 2007, 2011), and other seed characteristics such as seed coat hardness (Lundgren and Rosentrater 2007) in determining carabid preferences for particular weed seeds. However, other seed characteristics, such as nutritional quality of the seed and seed surface chemistry, might also play important roles in seed consumption. These mechanisms are not well-studied and need further investigation. Further, very limited attention has focused on the potential of carabid larvae in weed seed consumption. Developing efficient field sampling methods for carabid larvae could facilitate estimation of the possible role of carabid larvae in weed seed consumption.

The mechanisms involved in foraging and detecting weed seeds on the soil surface are not known. Carabid species such as Pterostichus melanarius use olfactory cues in habitat (Kielty et al. 1996; Tréfás et al. 2001) and prey selection (Kielty et al. 1996). However, the extent to which such cues are used in the foraging of seeds remains unexplored. Insights into foraging behavior and seedtracking mechanisms can improve our current understanding of species assembly dynamics, behavior, and time of the season for active foraging. The role of carabids in detecting and consuming seeds that are buried at different soil depths has been investigated to a limited extent (Harrison and Gallandt 2012; White et al. 2007), and needs to be considered further.

Several studies have investigated the potential of carabid beetles for weed management across Europe (Westerman et al. 2003a, Honek et al. 2005, 2007; Mauchline et al. 2005) and the United States (Gaines and Gratton 2010; Lundgren et al. 2013; Menalled et al. 2000b, 2007; Shearin et al.
2007, 2008; White et al. 2007). Despite having a rich carabid fauna in Canadian agroecosystems (Goulet 2003; Levesque and Levesque 1994; Lindroth 1957), the role of omnivorous and granivorous species in weed management has not been extensively studied. Although the effects of tillage on weed seed consumption by carabid beetles has been reported by Cromar et al. (1999), there is a large gap in studies focusing on different aspects of seed predation. In the last two decades, cropping practices have undergone major changes in the northern Great Plains region, such as intensive canola production (Canola Council of Canada 2014b), the use of herbicide-tolerant crops (Harker et al. 2000), and adoption of zero-tillage practices (Smyth et al. 2010). Studying weed seed consumption under these circumstances could help in understanding the weed seed consumer community and weed seed consumption patterns in this region.

\section{Acknowledgments}

We are grateful to the Alberta Canola Producers Commission and the Natural Sciences and Engineering Research Council (NSERC) for their generous funding to this project.

\section{Literature Cited}

Acorn JH, Ball GE (1991) The mandibles of some adult ground beetles: Structure, function, and the evolution of herbivory (Coleoptera: Carabidae). Can J Zool 69:638-650

Albert MJ, Escudero A, Iriondo JM (2005) Assessing ant seed predation in threatened plants: a case study. Acta Oecol 28:213-220

Alcock J (1976) The behaviour of the seed-collecting larvae of a carabid beetle (Coleoptera). J Nat Hist 10:367-375

Armstrong G, McKinlay RG (1997) Vegetation management in organic cabbages and pitfall catches of carabid beetles. Agric Ecosyst Environ 64:267-276

Arneberg P, Andersen J (2003) The energetic equivalence rule rejected because of a potentially common sampling error: evidence from carabid beetles. Oikos 101:367-375

Baguette M, Hance TH (1997) Carabid beetles and agricultural practices: influence of soil ploughing. Biol Agric Hortic 15:185-190

Baraibar B, Westerman PR, Recasens J (2009) Effects of tillage and irrigation in cereal fields on weed seed removal by seed predators. J Appl Ecol 46:380-387

Bewley JD, Black M (1994) Seeds: Physiology of Development and Germination. New York: Plenum Press. 445 p

Blubaugh CK, Caceres VA, Kaplan I, Larson J, Sadof CS, Richmond DS (2011) Ground beetle (Coleoptera: Carabidae) phenology, diversity and response to weed cover in a turfgrass ecosystem. Environ Entomol 40:1093-1101

Bohan DA, Boursault A, Brooks DR, Petit S (2011) Nationalscale regulation of the weed seedbank by carabid predators. J Appl Ecol 48:888-898 
Booij CJH, Noorlander J (1992) Farming systems and insect predators. Agric Ecosyst Environ 40:125-135

Bourassa S, Cárcamo HA, Spence JR (2010) Effects of crop rotation and genetically modified herbicide-tolerant corn on ground beetle diversity, community structure and activity density. Can Entomol 142:143-159

Boyetchko SM, Bailey KL, De Clerck-Floate RA (2009) Current biological weed control agents-their adoption and future prospects. Prairie Soils Crops 2:38-45

Brandmayr P, Bonacci T, Giglio A, Talarico FF, ZettoBrandmayr T (2009) The evolution of defence mechanisms in carabid beetles: a review. Pages 25-43 in Casellato S, Burighel P, Minelli A, eds. Life and Time: The Evolution of Life and its History. Padova: Cleup

Brandmayr P, Zetto-Brandmayr T (1979) The evolution of parental care phenomena in Pterostichine ground beetles with special reference to the genera Abax and Molops (Col. Carabidae). Pages 35-49 in den Boer PJ, Thiele HU, Weber $\mathrm{F}$, eds. On the evolution of behavour in carabid beetles. Wageningen, The Netherlands: Miscellenous Papers Landbouwhogescool Wageningen

Briggs JB (1965) Biology of some ground beetles (Col: Carabidae) injurious to strawberries. Bull Entomol Res 56:79-93

Brown JL, Reichman OJ, Davidson DW (1979) Granivory in desert systems. Ann Rev Ecol Syst 10:201-227

Brown KC, Lawton JH, Shires SW (1983) Effects of insecticides on invertebrate predators and their cereal aphid (Hemiptera: Aphididae) prey: laboratory experiments. Environ Entomol 12:1747-1750

Brust GE (1990) Direct and indirect effects of four herbicides on the activity of Carabid beetles (Coleoptera: Carabidae). Pest Sci 30:309-320

Brust GE (1994) Seed-predators reduce broadleaf weed growth and competitive ability. Agric Ecosyst Environ 48:27-34

Brust GE, House GJ (1988) Weed seed destruction by arthropods and rodents in low-input soybean agroecosystems. Am J Alt Agric 3:19-25

Campbell BC (1989) On the role of microbial symbiotes in herbivorous insects. Pages 1-44 in Bernays EA, ed. InsectPlant Interactions. Boca Raton FL: CRC Press

Canola Council of Canada (2014a) Canola Encyclopedia. http://www. canolacouncil.org/canola-encyclopedia/weeds/weed-management/\# canada-thistle. Accessed January 12, 2014

Canola Council of Canada (2014b) Market and Stats Branch. http:// www.canolacouncil.org/markets-stats/statistics/harvest-acreage/. Accessed February 11, 2014

Cárcamo HA (1995) Effect of tillage on ground beetles (Coleoptera: Carabidae): a farm-scale study in central Alberta. Can Entomol 127:631-639

Cárcamo HA, Niemala JK, Spence JR (1995) Farming and ground beetles: effects of agronomic practice on populations and community structure. Can Entomol 127:123-140

Cárcamo HA, Spence JR (1994) Crop type effects on the activity and distribution of ground beetles (Coleoptera: Carabidae). Environ Entomol 23:684-692

Cardina J, Norquay HM, Stinner BR, McCartney DA (1996) Postdispersal predation of velvetleaf (Abutilon theophrasti) seeds. Weed Sci 44:534-539

Carmona DM, Landis DA (1999) Influence of refuge habitats and cover crops on seasonal activity-density of ground beetles (Coleoptera: Carabidae) in field crops. Biol Control 28:1145-1153
Carmona DM, Menalled FD, Landis DA (1999) Gryllus pennsylvanicus (Orthoptera: Gryllidae): laboratory weed seed predation and within field activity-density. J Econ Entomol 92:825-829

Chambers JC, MacMahon JA (1994) A day in the life of a seed: movements and fates of seeds and their implications for natural and managed systems. Annu Rev Ecol Syst 25:263-292

Chauhan BS, Migo T, Westerman PR, Johnson DE (2010) Postdispersal predation of weed seeds in rice fields. Weed Res 50:553-560

Cousens RD, Dale MRT, Taylor J, Law R, Moerkerk M, Kembel SW (2006) Causes of pattern in plant communities where environmental change is rapid and species longevity is short. J Veg Sci 17:509-524

Crawley MJ (2000) Seed predators and plant population dynamics. Pages 167-182 in Fenner M, ed. Seeds: The Ecology of Regeneration in Plant Communities. Wallingford, UK: CABI Publishing

Crist TO, MacMahon JA (1992) Harvester ant foraging and shrub-steppe seeds: interactions of seed resources and seed use. Ecology 73:1768-1779

Cromar HE, Murphy SD, Swanton CJ (1999) Influence of tillage and crop residue on postdispersal predation of weed seeds. Weed Sci 47:184-194

Crowson RA, ed (1981). The Biology of the Coleoptera. London: Academic Press. 802 p

Davis AS, Liebman M (2003) Cropping system effects on giant foxtail (Setaria faberi) demography: I. Green manure and tillage timing. Weed Sci 51:919-929

Davis AS, Raghu S (2010) Weighing abiotic and biotic factors in weed seed predation. Weed Res 50:402-412

Davis AS, Taylor EC, Haramoto ER, Renner KA (2013) Annual postdispersal weed seed predation in contrasting field environments. Weed Sci 61:296-302

Derksen DA, Anderson RL, Blackshaw RE, Maxwell B (2002) Weed dynamics and management strategies for cropping systems in the northern Great Plains. Agron J 94:174-185

Desender K, Maeelfaitj P, Dhulsterm M, Vanhercke L (1981) Ecological and faunal studies on Coleoptera in agricultural land. I. Seasonal occurrence of Carabidae in the grassy edge of a pasture. Pedobiologia 2:379-384

Diekotter T, Wamser S, Wolters V, Birkhofer K (2010) Landscape and management effects on structure and function of soil arthropod communities in winter wheat. Agric Ecosyst Environ 137:108-112

Dritschilo W, Wanner D (1980) Ground beetle abundance in organic and conventional corn fields. Environ Entomol 9:629-631

Ellsbury MM, Powell JE, Forcella F, Woodson WD, Clay SA, Riedell WE (1998) Diversity and dominant species of ground beetle assemblages (Coleoptera: Carabidae) in crop rotation and chemical input systems for the northern Great Plains. Ann Entomol Soc Am 91:619-625

Evans MEG (1977) Locomotion in the Coleoptera Adephaga, especially Carabidae. J Zool 181:189-226

Evans MEG (1986) Carabid locomotor habits and adaptations. Pages 59-57 in den Boer PJ, Luff ML, Mossakowski D, Weber F, eds. Carabid Beetles. Their Adptations and Dynamics. Stuttgart New York: Fischer Verlag

Evans MEG (1994) The carabid body plan: a functional interpretation. Pages 25-31 in Desender K, Dufrene M, Loreau M, Luff ML, Maelfait JP, eds. Carabid Beetles: Ecology

Kulkarni et al.: Granivorous ground beetles: a review • 371 
and Evolution. Dordrecht, The Netherlands: Springer Netherlands

Evans MEG, Forsythe TG (1985) Feeding mechanisms and their variation in form of some adult ground-beetles (Coleoptera: Caraboidea). J Zool 206:113-143

Fadl A, Purvis G, Towet K (1996) The effect of time of soil cultivation on the incidence of Pterostichus melanarius (Illig) (Coleoptera: Carabidae) in arable land in Ireland. Pedobiologia 42:171-183

Fawki S, Toft S (2005) Food preferences and the value of animal food for the carabid beetle Amara similata (Gyll) (Col Carabidae). J Appl Entomol 129:551-556

Fielding D, Defoliart JLS, Hagerty AM (2013) Effects of carbaryl-bran bait on trap-catch and seed predation by ground beetles. J Econ Entomol 106:669-674

Fischer C, Thies C, Tscharntke T (2011) Mixed effects of landscape complexity and farming practice on weed seed removal. Perspect Plant Ecol 13:297-303

Floate KD, Elliott RH, Doane JF, Gillott C (1989) Field bioassay to evaluate contact and residual toxicities of insecticides to carabid beetles (Coleoptera: Carabidae). J Econ Entomol 82:1543-1547

Flohre A, Fischer C, Aavik T, Bengtsson J, Berendse F, Bommarco R, Ceryngier P, Clement LW, Dennis C, Eggers S, Emmerson M, Geiger F, Guerrero I, Hawro V, Inchausti P, Liira J, Morales MB, Onate JJ, Part T, Weisser WW, Winqvist C, Thies C, Tscharntke T (2011) Agricultural intensification and biodiversity partitioning in European landscapes comparing plants, carabids and birds. Ecol Appl 21:1772-1781

Forbes SA (1883) The food relations of the Carabidae and the Coccinellidae. Bull Ill State Lab Nat Hist 1:33-64

Forsythe TG (1981) Running and pushing in relationship to hind leg structure in some Carabidae (Coleoptera). Coleopt Bull 35:353-378

Forsythe TG (1983) Mouthparts and feeding of certain ground beetles (Coleoptera: Carabidae). Zool J Linn Soc 79:319-376

Forsythe TG (1991) Feeding and locomotory functions in relation to body form in five species of ground beetle (Coleoptera: Carabidae). J Zool 223:233-263

Fox AF, Reberg-Horton SC, Orr DB, Moorman CE, Frank SD (2013) Crop and field border effects on weed seed predation in thesoutheastern US coastal plain. Agric Ecosyst Environ 177:58-62

Frank SD, Shrewsbury PM, Denno RF (2010) Effects of alternative food on cannibalism and herbivore suppression by carabid larvae. Ecol Entomol 35:61-68

Frank SD, Shrewsbury PM, Denno RF (2011) Plant versus prey resources: influence on omnivore behavior and herbivore suppression. Biol Control 57:229-235

Gaines HR, Gratton C (2010) Seed predation increases with ground beetle diversity in Wisconsin (USA) potato agroecosystems. Agric Ecosyst Environ 137:329-336

Gallandt ER, Molloy T, Lynch RP, Drummond FA (2005) Effect of cover-cropping systems on invertebrate seed predation. Weed Sci 53:69-76

Ghersa CM, Benech-Arnold RL, Satorre EH, Martínez-Ghersa MA (2000) Advances in weed management strategies. Field Crops Res 67:95-104

Goldschmidt H, Toft S (1997) Variable degrees of granivory and phytophagy in insectivorous carabid beetles. Pedobiologia 41:521-525

Goulet H (2003) Biodiversity of ground beetles (Coleoptera: Carabidae) in Canadian agricultural soils. Can J Soil Sci 83:259-264
Green RE (1984) The feeding ecology and survival of partridge chicks (Alectoris rufa and Perdix perdix) on arable farmland in east Anglia. J Appl Ecol 21:817-830

Hammond PM (1979) Wing-folding mechanisms in beetles with special reference to investigations of adephagan phylogeny (Coleoptera). Pages 113-180 in Erwin TL, Ball GE, Whitehead D, Halpern AL, eds. Carabid Beetles: Their Evolution, Natural History, and Classification. The Hague, The Netherlands: Dr. W. Junk Publishers

Harker KN, Blackshaw RE, Kirkland KJ, Derksen DA, Wall D (2000) Herbicide-tolerant canola: weed control and yield comparisons in western Canada. Can J Plant Sci 80:647-654

Harper JL (1977) Population Biology of Plants. London: Academic Press. $892 \mathrm{p}$

Harrison SK, Gallandt ER (2012) Behavioural studies of Harpalus rufipes De Geer: an important weed seed predator in northeastern US agroecosystems. Int J Ecol. DOI:101155/ 2012/846546, $6 \mathrm{p}$

Harrison SK, Regnier EE, Schmoll JT (2003) Postdispersal predation of giant ragweed (Ambrosia trifida) seed in no-tillage corn. Weed Sci 51:955-964

Hartke A, Drummond FA, Liebman M (1998) Seed feeding, seed caching and burrowing behaviors of Harpalus rufipes De Geer larvae (Coleoptera: Carabidae) in the Maine potato agroecosystem. Bio Control 13:91-100

Hatten TD, Bosque-Perez NA, Labonte JR, Guy SO, Eigenbrode SD (2007) Effects of tillage on the activity density and biological diversity of carabid beetles in spring and winter crops. Environ Entomol 36:356-368

Heggenstaller AH, Menalled FD, Liebman M, Westerman PR (2006) Seasonal patterns in post-dispersal seed predation of Abutilon theophrasti and Setaria faberi in three cropping systems. J Appl Ecol 43:999-1010

Holland JM (1998) Comparative impact of insecticide treatments on beneficial invertebrates in conventional and integrated farming systems. Pages 267-278 in Haskell PT, McEwen P, eds. Ecotoxicology: Pesticides and Beneficial Organism. Dordrecht, The Netherlands: Kluwer Academic Publishers

Holland JM, Luff ML (2000) The effects of agricultural practices on Carabidae in temperate agroecosystems. Integrated Pest Manag Rev 5:109-129

Holland JM, Perry JN, Winder L (1999) The within field spatial and temporal distribution of arthropods in winter wheat. Bull Entomol Res 89:499-513

Holland JM, Winder L, Perry JN (2000) The impact of dimethoate on the spatial distribution of beneficial arthropods. Ann Appl Biol 136:93-105

Holliday NJ, Hagley EAC (1984) The effect of sod type on the occurrence of ground beetles (Coleoptera: Carabidae) in a pest management apple orchard. Can Entomol 116:165-171

Holm FA, Johnson EN (2009) The history of herbicide use for weed management on the prairies. Prairie Soils Crops 2:1-11

Honek A, Jarosik V (2000) The role of crop density, seed and aphid presence in diversification of field communities of Carabidae. Eur J Entomol 97:517-525

Honek A, Martinkova Z, Jarosik V (2003) Ground beetles (Carabidae) as seed predators. Eur J Entomol 100:531-544

Honek A, Martinkova Z, Saska P (2005) Post-dispersal seed predation of Taraxacum officinale (dandelion) seed. J Ecol 93:310-318

Honek A, Martinkova Z, Saska P (2011) Effect of size taxonomic affiliation and geographic origin of dandelion (Taraxacum agg)

372 • Weed Science 63, April-June 2015 
seeds on predation by ground beetles (Carabidae Coleoptera). Basic Appl Ecol 12:89-96

Honek A, Martinkova Z, Saska P, Koprdova S (2009) Role of post-dispersal seed and seedling predation in establishment of dandelion (Taraxacum agg) plants. Agric Ecosyst Environ 134:126-135

Honek A, Martinkova Z, Saska P, Pekar S (2007) Size and taxonomic constraints determine the seed preferences of Carabidae (Coleoptera). Basic Appl Ecol 8:343-353

Honek A, Saska P, Martinkova Z (2006) Seasonal variation in seed predation by adult carabid beetles. Entoml Exp Appl 118:157-162

House GJ, Parmelee RW (1985) Comparison of soil arthropods and earthworm from conventional and no-tillage agroecosystems. Soil Tillage Res 5:351-360

Hulme PE (1998) Post-dispersal seed predation: consequences for plant demography and evolution. Perspect Plant Ecol Evol Syst 1:32-46

Hulme PE (2002) Seed-eaters: Seed dispersal, destruction and demography. Pages 257-274 in Levey DJ, Silva WR, Galetti M, eds. Seed Dispersal and Frugivory: Ecology, Evolution and Conservation. Wallingford, UK: CAB International

Hummel JD, Dosdall LM, Clayton GW, Harker KN, O’Donovan JT (2012) Ground beetle (Coleoptera: Carabidae) diversity, activity density and community structure in a diversified agroecosystem. Environ Entomol 41:72-80

Hůrka K (1996) Carabidae of the Czech and Slovak Republics. 1st edn. Zlín, Czeck Republik: Kabourek. 565 p

Hůrka K (1998) Larval taxonomy development and diet of Amara (Amara) famelica $A(\mathrm{~A})$, littorea and $A(A)$ proxima (Coleoptera: Carabidae: Amarina). Acta Soc Zool Bohem 62:105-113

Hůrka K, Jarosik V (2001) Development, breeding type and diet of members of the Amara communis species aggregate (Coleoptera: Carabidae). Acta Soc Zool Bohem 65:17-23

Hůrka K, Jarosik V (2003) Larval omnivory in Amara aenea (Coleoptera: Carabidae). Eur J Entomol 100:329-335

Inouye DW (1980) The terminology of floral larceny. Ecology 61:1251-1253

Janzen DH (1971) Seed predation by animals. Annu Rev Ecol Syst 2:465-492

Jonason D, Smith HG, Bengtsson J, Birkhofer K (2013) Landscape simplification promotes weed seed predation by carabid beetles (Coleoptera: Carabidae). Landscape Ecol 28:487-494

Jones GD (1984) Microorganisms as mediators of plant resource exploitation by insect herbivores. Pages 53-99 in Price PW, Slobodchikoff CN, Gaud WS, eds. A New Ecology: Novel Approaches to Interactive Systems. New York: Wiley

Jørgensen HB, Toft S (1997) Food preference, diet dependent fecundity and larval development in Harpalus rufipes (Coleoptera: Carabidae). Pedobiologia 41:307-315

Juliano SA (1985) The effects of body size on mating and reproduction in Brachinus lateralis (Coleoptera, Carabidae). Ecol Entomol 10:271-280

Julien MH (1992) Biological Control of Weeds: A World Catalogue of Agents and Their Target Weeds. Wallingford, UK: CAB International. $223 \mathrm{p}$

Kielty JP, Allen-Williams LJ, Underwood N, Eastwood EA (1996) Behavioral responses of three species of ground beetle (Coleoptera: Carabidae) to olfactory cues associated with prey and habitat. J Insect Behav 9:237-250
Kirk VM (1972) Seed-caching by larvae of two ground beetles Harpalus pensylvanicus and H erraticus. Ann Entomol Soc Am 65:1426-1428

Klimes P, Saska P (2010) Larval and adult seed consumption affected by the degree of food specialization in Amara (Coleoptera: Carabidae). J Appl Entomol 134:659-666

Kollmann J, Coomes DA, White SM (1998) Consistencies in post-dispersal seed predation of temperate fleshy-fruited species among season, years and sites. Funct Ecol 12:683-690

Koprdová S, Saska P, Honek A, Martinková Z (2012) Susceptibility of the early growth stages of volunteer oilseed rape to invertebrate predation. Plant Prot Sci 48:44-50

Kotze DJ, Brandmayr P, Casale A, Dauffy-Richard E, Dekoninck W, Koivula M, Lövei GL, Mossakowski D, Noordijk J, Paarmann W, Pizzolotto R, Saska P, Schwerk A, Serrano J, Szyszko J, Taboada A, Turin H, Venn S, Vermeulen R, Zetto T (2011) Forty years of carabid beetle research in Europe-from taxonomy, biology, ecology and population studies to bioindication, habitat assessment and conservation. ZooKeys 100:55-148

Kremer RJ, Spencer NR (1989) Impact of a seed-feeding insect and microorganisms on velvetleaf (Abutilon theophrasti) seed viability. Weed Sci 37:211-216

Kromp B (1989) Carabid beetle communities (Carabidae Coleoptera) in biologically and conventionally farmed agroecosystems. Agric Ecosyst Environ 27:241-251

Kromp B (1990) Carabid beetles (Coleoptera Carabidae) as bioindicators in biological and conventional farming in Austrian potato fields. Biol Fertil Soils 9:182-187

Kromp B (1999) Carabid beetles in sustainable agriculture: a review on pest control efficacy cultivation impact and enhancement. Agric Ecosyst Environ 74:187-228

Lalonde O, Légère A, Stevenson FC, Roy M, Vanasse A (2012) Carabid beetle communities after 18 years of conservation tillage and crop rotation in a cool humid climate. Can Entomol 144:645-657

Larochelle A (1990) The Food of Carabid Beetles (Coleoptera: Carabidae, including Cicindelinae). Fabreries Suppl 5. Quebec City, Quebec, Canada: Sillery: Association des entomologistes amateurs du Québec. $132 \mathrm{p}$

Lee JC, Menalled FD, Landis DA (2001) Refuge habitats modify impact of insecticide disturbance on carabid beetle communities. J Appl Ecol 38:472-483

Leeson JY, Thomas AG, Hall LM, Brenzel CA, Andrews T, Brown KR, Van Acker RC (2005) Prairie weed surveys of cereal, oilseed and pulse crops from the 1970s to the 2000s. Saskatoon, Saskatchewan, Canada: Agriculture and Agri-Food Canada Weed Survey Series. 395 p

Levesque C, Levesque G (1994) Abundance and seasonal activity of ground beetles (Coleoptera: Carabidae) in a raspberry plantation and adjacent sites in southern Quebec (Canada). J Kans Entomol Soc 67:73-101

Liebman M, Gallandt ER (1997) Many little hammers: ecological management of crop-weed interactions. Pages 291-343 in Jackson LE, ed. Ecology in Agriculture. San Diego CA: Academic Press

Lindroth CH (1957) The Faunal Connections between Europe and North America. New York: Wiley. 344 p

Lindroth CH (1961-1969) The ground beetles (Carabidae, excluding Cicindelinae) of Canada and Alaska. Opusca Entomol, Suppl. 20, 24, 29, 33, 34, 35. Part I, pages IXLVIII, 1969. Part II, pages 1-200, 1961. Part III, pages 201- 
408, 1963. Part IV, pages 409-648, 1966. Part V, pages 649944, 1968. Part VI, pages 945-1192

Lindroth CH (1992) Ground Beetles (Carabidae) of Fennoscandia: A Zoogeographic Study. Part III. Washington DC: Smithsonian Institution Libraries and National Science Foundation. $814 \mathrm{p}$

Louda SM (1989) Predation in the dynamics of seed generation. Pages 25-51 in Leck MA, Parker VT, Simpson RL, eds. Ecology of Soil Seed Banks. New York: Academic Press

Lovei G, Sunderland K (1996) Ecology and behavior of ground beetles (Coleoptera: Carabidae). Annu Rev Entomol 41:231256

Luff ML (1980) The biology of the ground beetle Harpalus rufipes in a strawberry field in Northumberland. Ann Appl Biol 94:153-164

Luff ML (1993) The Carabidae (Coleoptera) Larvae of Fennoscandia and Denmark. Fauna Entomologica Scandinavica 27. Leiden, The Netherlands: EJ Brill Academic Publishers. $186 \mathrm{p}$

Lund RD, Turpin FT (1977) Carabid damage to weed seeds found in Indiana cornfields. Environ Entomol 6:695-698

Lundgren JG (2005) Ground beetles as weed control agents: the influence of farm management on granivory. Am Entomol 51:224-226

Lundgren JG (2009) Relationships of Natural Enemies and Non-Prey Foods. Dordrecht, The Netherlands: Springer International. $454 \mathrm{p}$

Lundgren JG, Lehman RM (2010) Bacterial gut symbionts contribute to seed digestion in an omnivorous beetle. PLoS ONE 5:e10831

Lundgren JG, Rosentrater KA (2007) The strength of seeds and their destruction by granivorous insects. Arthropod Plant Interact 1:93-99

Lundgren JG, Saska P, Honek A (2013) Molecular approach to describing a seed-based food web: the post-dispersal granivore community of an invasive plant. Ecol Evol 3:1642-1652

Lundgren JG, Shaw JT, Zaborski ER, Eastman CE (2006) The influence of organic transition systems on beneficial grounddwelling arthropods and predation of insects and weed seeds. Renew Agr Food Syst 21:227-237

Manley G (1996) Relationship between selected intercropped ground covers and soil arthropod populations in a no-till crop rotation system in western St. Joseph County, Michigan (year one 1995 corn). in Proceedings of the Cover Crop Symposium. Michigan State University, East Lansing, MI. Battle Creek, Michigan: Michigan State University

Marino PC, Westerman PR, Pinkert C, van der Werf W (2005) Influence of seed density and aggregation on post-dispersal weed seed predation in cereal fields. Agric Ecosyst Environ 106:17-25

Marko V, Kadar F (2005) Effects of different insecticide disturbance levels and weed patterns on carabid beetle assemblages. Acta Phytopath Entomol Hungaric 40:111-143

Martinkova Z, Saska P, Honek A (2006) Consumption of fresh and buried seed by ground beetles (Coleoptera: Carabidae). Eur J Entomol 103:361-364

Mauchline AL, Watson SJ, Brown VK, Froud-Williams RJ (2005) Post-dispersal seed predation of non-target weeds in arable crops. Weed Res 45:157-164

Menalled F, Landis D, Lee J, White S, Renner K (2000a) Ecology and Management of Weed Seed Predators in Michigan Agroecosystems. Extension Bulletin E-2716. East Lansing, MI: Michigan State University. 6 p
Menalled FD, Marino PC, Renner KA, Landis DA (2000b) Post-dispersal weed seed predation in Michigan crop fields as a function of agricultural landscape structure. Agric Ecosyst Environ 77:193-202

Menalled FD, Smith RG, Dauer JT, Fox TB (2007) Impact of agricultural management on carabid communities and weed seed predation. Agric Ecosyst Environ 118:49-54

Motzke I, Tscharntke T, Sodhi NS, Klein AM, Wanger TC (2013) Ant seed predation, pesticide applications and farmer's income from tropical multi-cropping gardens. Agric For Entomol 15:245-254

Navntoft S, Esbjerg P, Riedel W (2006) Effects of reduced pesticide dosages on carabids (Coleoptera: Carabidae) in winter wheat. Agric For Entomol 8:57-62

Noroozi S, Alizadeh HM, Mashhadi HR (2012) Factors Affecting Postdispersal Weed Seed Predation in Barely Fields. ISRN Agron DOI: 10.5402/2012/461245

Nystrand O, Granstrom A (2000) Predation on Pinus sylvestris seeds and juvenile seedlings in a Swedish boreal forest in relation to stand disturbance by logging. J Appl Ecol 37:449-463

O’Rourke ME, Heggenstaller AH, Liebman M, Rice ME (2006) Post-dispersal weed seed predation by invertebrates in conventional and low-external-input crop rotation systems. Agric Ecosyst Environ 116:280-288

Paarmann W, Faust N, Arndt E, Luchtrath I, Rohe W (2006) Constant seed size and mandible growth - a fundamental problem for granivorous ground beetle larvae (Coleoptera: Carabidae). Entomol Fenn 17:334-339

Pausch RD, Pausch LM (1980) Observations on the biology of the slender seedcorn beetle Clivina impressifrons (Coleoptera: Carabidae). Great Lakes Entomol 13:189-194

Perfecto I, Horwith B, Vandermeer J, Schultz B, McGuinness H, Dos Santos A (1986) Effects of plant diversity and density on the emigration of two ground beetles Harpalus pensylvanicus and Evarthrus sodalist (Coleoptera: Carabidae) in a system of tomatoes and beans. Environ Entomol 15:1028-1031

Pimentel D, Hepperly P, Hanson J, Seidel R, Douds D (2005) Environmental energetic and economic comparisons of organic and conventional farming systems. Bioscience 55:573-582

Poulsen JG, Sotherton NW, Aebischer NJ (1998) Comparative nesting and feeding ecology of skylarks Alauda arvensis on arable farmland in southern England with special reference to set-aside. J Appl Ecol 35:131-147

Povey FD, Smith H, Watt TA (1993) Predation of annual grass weed seeds in arable field margins. Ann Appl Biol 122:323-328

Purtauf T, Dauber J, Wolters V (2005) The response of carabids to landscape simplification differs between trophic groups. Oecologia 142:458-464

Ready CC, Vinson SB (1995) Seed selection by the red imported fire ant (Hymenoptera: Formicidae) in the laboratory. Environ Entomol 24:1422-1431

Rew LJ, Cussans GW, Mugglestone MA, Miller PCH (1996) A technique for mapping the spatial distribution of Elymus repens L. with estimates of the potential reduction in herbicide usage from patch spraying. Weed Res 36:283-292

Ricketts T, Regetz J, Steffan-Dewenter I, Cunningham SA, Kremen C, Bogdanski A, Gemmill-Herren B, Greenleaf SS, Klein AM, Mayfield MM, Morandin LA, Ochieng A, Viana FB (2008) Landscape effects on crop pollination services: are there general patterns? Ecol Lett 11:499-515 
Rivard I (1966) Ground beetles (Coleoptera: Carabidae) in relation to agricultural crops. Can Entomol 98:189-195

Saska P (2005) Contrary food requirements of the larvae of two Curtonotus (Coleoptera: Carabidae: Amara) species. Ann Appl Biol 147:139-144

Saska P (2008a) Granivory in terrestrial isopods. Ecol Entomol 33:742-747

Saska P (2008b) Effect of diet on the fecundity of three carabid beetles. Physiol Entomol 30:188-192

Saska P, Jarosik V (2001) Laboratory study of larval food requirements in nine species of Amara (Coleoptera: Carabidae). Plant Prot Sci 37:103-110

Saska P, Koprdova S, Martinkova Z, Honek A (2014) Comparing methods of weed seed exposure to predators. Ann Appl Biol 164:301-312

Saska P, Martinkova Z, Honek A (2010) Temperature and rate of seed consumption by ground beetles (Carabidae). Biol Control 52:91-95

Saska P, van der Werf W, de Vries E, Westerman PR (2008) Spatial and temporal patterns of carabid activity density in cereals do not explain levels of predation on weed seeds. Bull Entomol Res 98:169-181

Saska P, van der Werf W, Hemerik L, Luff ML, Hatten TD, Honek A (2013) Temperature effects on pitfall catches of epigeal arthropods: a model and method for bias correction. J Appl Ecol 50:181-189

Sasakawa K (2010a) Field observations of climbing behavior and seed predation by adult ground beetles (Coleoptera: Carabi$\mathrm{dae})$ in a lowland area of the temperate zone. Environ Entomol 39:1564-1560

Sasakawa K (2010b) Laboratory studies on the larval food habits of the ground beetle Amara (Curtonotus) gigantea (Motschulsky) (Coleoptera: Carabidae: Zabrini). Entomol Sci $13: 358-362$

Schremmer F (1960) Beitrag zur Biologie von Ditomus clypeatus Rossi, eines körnersammelnden Carabiden. Z Arbgem Osterer Entomol 3:140-146

Shearin AF, Reberg-Horton SC, Gallandt ER (2007) Direct effects of tillage on the activity density of ground beetle (Coleoptera: Carabidae) weed seed predators. Environ Entomol 36:1140-1146

Shearin AF, Reberg-Horton SC, Gallandt ER (2008) Cover crop effects on the activity-density of the weed seed predator Harpalus rufipes (Coleoptera: Carabidae). Weed Sci 56:442450

Shuler RE, DiTommaso A, Losey JE, Mohler CL (2008) Postdispersal weed seed predation is affected by experimental substrate. Weed Sci 56:889-895

Smyth S, Gusta M, Phillips P, Castle D (2010) Assessing the Economic and Ecological Impacts of Herbicide Tolerant Canola in Western Canada. http://wwwcanolacouncilorg/media/504427/ assessing_the_economic_and_ecological_impacts_of_herbicide_ tolerant_canola_in_western_canadapdf. Accessed March 11, 2014

Speight MR, Lawton JH (1976) The influence of weed-cover on the mortality imposed on artificial prey by predatory ground beetles in cereal fields. Oecologia (Berl) 23:211-233

Spence JR, Niemelä JK (1994) Sampling carabid assemblages with pitfall traps: the madness and the method. Can Entomol 126:881-894

Stinner BR, House GJ (1990) Arthropods and other invertebrates in conservation tillage agriculture. Annu Rev Entomol 35:299-318
Stinner BR, McCartney DA, van Doren DM, Jr (1988) Soil and foliage arthropod communities in conventional reduced and no-tillage corn (maize Zea mays L.) systems: a comparison after 20 years of continuous cropping. Soil Tillage Res 11:47-58

Swanton CJ, Murphy SD (1996) Weed science beyond the weeds: the role of integrated weed management (IWM) in agroecosystem health. Weed Sci 4:437-445

Thiele HU (1977) Carabid Beetles in Their Environments. A study on Habitat Selection by Adaptation in Physiology and Behavior. Berlin, Germany: Springer-Verlag. 369 p

Thomas CFG, Green F, Marshall EJP (1997) Distribution, dispersal and population size of the ground beetles, Pterostichus melanarius (Illiger) and Harpalus rufipes (Degeer) (Coleoptera, Carabidae), in field margin habitats. Biol Agric Hortic 15:337-352

Thompson RG (1979) A systematic study of the larvae in the tribes Pterostichini, Morionini and Amarini (Coleoptera: Carabidae). University of Arkansas Bulletin No. 837. Fayetteville, AR: Agricultural Experiment Station. 105 p

Tooley JA, Brust GE (2002) Weed seed predation by carabid beetles. Pages 215-230 in Holland JM, ed. The Agroecology of Carabid Beetles. Andover UK: Intercept Ltd

Tooming E, Merivee E, Must A, Sibul I, Williams I (2014) Sublethal effects of the neurotoxic pyrethroid insecticide Fastac ${ }^{\circledR}$ $50 \mathrm{EC}$ on the general motor and locomotor activities of the non-targeted beneficial carabid beetle Platynus assimilis (Coleoptera: Carabidae). Pest Manage Sci 70:959-966

Tréfás H, Canning H, McKinlay RG, Armstrong G, Bujáki G (2001) Preliminary experiments on the olfactory responses of Pterostichus melanarius Illiger (Coleoptera: Carabidae) to intact plants. Agric For Entomol 3:71-76

Tréfás H, van Lenteren JC (2008) Egg-laying site preferences of Pterostichus melanarius in mono- and intercrops. Bull Insectol 61:225-231

Trichard A, Alignier A, Biju-Duval L, Petit S (2013) The relative effects of local management and landscape context on weed seed predation and carabid functional groups. Basic Appl Ecol 14:235-245

Tscharntke T, Klein AM, Kruess A, Steffan-Dewenter I, Thies C (2005) Landscape perspectives on agricultural intensification and biodiversity-ecosystem service management. Ecol Lett 8:857-874

Tscharntke T, Tylianakis JM, Rand TA, Didham RK, Fahrig L, Batáry P, Bengtsson J, Clough Y, Crist TO, Dormann CF, Ewers RM, Fründ J, Holt RD, Holzschuh A, Klein AM, Kleijn D, Kremen C, Landis DA, Laurance W, Lindenmayer D, Scherber C, Sodhi N, Steffan-Dewenter I, Thies C, van der Putten WH, Westphal C (2012) Landscape moderation of biodiversity patterns and processes-eight hypotheses. Biol Rev 87:661-685

Tukarhiwa EM, Coaker TH (1982) Effect of mixed cropping on some insect pests of brassicas: reduced Brevicoryne brassicae infestations and influences on epigeal predators and the disturbance of oviposition behaviour in Delia brassicae. Entomol Exp Appl 32:129-140

Tyler BMJ, Ellis C (1979) Ground beetles in three tillage plots in Ontario and observations on their importance as predators of the northern corn rootworm Diabrotica longicornis (Coleoptera: Chrysomelidae). Pages 65-73 in Proceedings of the Entomological Society of Ontario. Guelph, Ontario, Canada: Entomological Society of Ontario

Vanbergen AJ, Woodcock BA, Koivula M, Niemelä J, Kotze DJ, Bolger T, Golden V, Dubs F, Boulanger G, Serrano J, Lencina

Kulkarni et al.: Granivorous ground beetles: a review • 375 
JL, Serrano A, Aguiar C, Grandchamp AC, Stofer S, Szél G, Ivits E, Adler P, Markus J, Watt AD (2010) Trophic level modulates carabid beetle responses to habitat and landscape structure: a pan-European study. Ecol Entomol 35:226-235

Van der Wall SB (1998) Foraging success of granivorous rodents: effects of variation in seed and soil water on olfaction. Ecology 79:233-241

Wallin H, Chiverton PA, Ekbom BS, Borg A (1992) Diet, fecundity and egg size in some polyphagous predatory carabid beetles. Entomol Exp Appl 65:129-140

Ward MJ, Ryan MR, Curran WS, Barbercheck ME, Mortensen DA (2011) Cover crops and disturbance influence activitydensity of weed seed predators Amara aenea and Harpalus pensylvanicus (Coleoptera: Carabidae). Weed Sci 59:76-81

Watson SJ, Mauchline AL, Brown VK, Froud-Williams RJ (2003) Post-dispersal losses of Stellaria media and Polygonum aviculare seeds in spring barley (Hordeum vulgare). Asp Appl Biol 69:203-208

Westerman PR, Atanackovic V, Royo-Esnal A, Torra J (2012) Differential weed seed removal in dryland cereals. Arthropod Plant Interact 6:591-599

Westerman PR, Borza JK, Andjelkovic J, Liebman M, Danielson B (2008) Density-dependent predation of weed seeds in maize fields. J Appl Ecol 45:1612-1620

Westerman PR, Dixon PM, Liebman M (2009) Burial rates of surrogate seeds in arable fields. Weed Res 49:142-152

Westerman PR, Hofman A, Vet LEM, van der Werf W (2003a) Relative importance of vertebrates and invertebrates in epigeaic weed seed predation in organic cereal fields. Agri. Ecosyst Environ 95:417-425

Westerman PR, Liebman M, Heggenstaller AH, Forcella F (2006) Integrating measurements of seed availability and removal to estimate weed seed losses due to predation. Weed Sci 54:566-574

Westerman PR, Liebman M, Menalled FD, Heggenstaller A, Hartzler RG, Dixon PM (2005) Are many little hammers effective? Velvetleaf (Abutilon theophrasti) population dynamics in two- and four-year crop rotation systems. Weed Sci 53:382-392

Westerman PR, Luijendijk CD, Wevers JDA, van der Werf W (2011) Weed seed predation in a phenologically late crop. Weed Res 51:157-164

Westerman PR, Wes JS, Kropff MJ, van der Werf W (2003b) Annual losses of weed seeds due to predation in organic cereal fields. J Appl Ecol 40:824-836
White S, Renner AK, Menalled FD, Landis DA (2007) Feeding preferences of weed seed predators and effect on weed emergence. Weed Sci 55:606-612

Winquist C, Bengtsson J, Aavik T, Berendse F, Clement LW, Eggers S, Fischer C, Flohre A, Geiger F, Liira J, Part T, Thies C, Tscharntke T, Weisser WW, Bommarco R (2011) Mixed effects of organic farming and landscape complexity on farmland biodiversity and biological control potential across Europe. J Appl Ecol 48:570-579

Zetto-Brandmayr T (1976) Studi sulla fitofagia nei Carabidi: spermofagia larvale di Ophonus ardosiacus Lutsh (Coleoptera: Carabidae). Pages 59-67 in XI Congresso Nazionale Italiano di Entomologia. Portici-Sorrento, Italy

Zetto-Brandmayr T (1983) Life cycle, control of propagation rhythm and fecundity of Ophonus rotundicollis Fairm. et Lab. (Coleoptera, Carabidae, Harpalini) as an adaptation to the mainfeeding plant Daucus carota L. (Umbelliferae). Pages 93-103 in Brandmayr P, den Boer PJ, Weber E, eds. Ecology of Carabids: The Synthesis of Field Study and Laboratory Experiment. Wageningen: Centre for Agricultural Publishing and Documentation

Zetto-Brandmayr T (1990) Spermophagous (seed-eating) ground beetles: first comparison of the diet and ecology of the Harpaline genera Harpalus and Ophonus (Col Carabidae). Pages 307-316 in Stork NE, ed. The Role of Ground Beetles in Ecological and Environmental Studies. Andover, UK: Intercept Ltd

Zetto-Brandmayr T, Giglio A, Marano I, Brandmayr P (1998) Morphofunctional and ecological features in carabid (Coleoptera) larvae. Pages 449-489 in Ball GE, Casale A, Taglianti V, eds. Phylogeny and Classification of Caraboidea. Proceedings of a Symposium, XX International Congress of Entomology. Torino, Italy: Museo Regionale di Scienze Naturali

Zhang J, Drummond FA, Liebman M, Hartke A (1997) Insect predation of seeds and plant population dynamics. Technical Bulletin 163, Maine Agricultural and Forest Experiment Station. Orano, ME: University of Maine. $32 \mathrm{p}$

Zhavoronkova TN (1969) Certain structural peculiarities of the Carabidae (Coleoptera) in relation to their feeding habits. Entomol Rev 48:462-471

Received April 28, 2014, and approved November 21, 2014. 